\title{
Widespread Expression of the AMPA Receptor GluR2 Subunit at Glutamatergic Synapses in the Rat Spinal Cord and Phosphorylation of GluR1 in Response to Noxious Stimulation Revealed with an Antigen-Unmasking Method
}

\author{
Gergely G. Nagy, ${ }^{1}$ Muna Al-Ayyan, ${ }^{1}$ David Andrew, ${ }^{1}$ Masahiro Fukaya, ${ }^{2}$ Masahiko Watanabe, ${ }^{2}$ and Andrew J. Todd ${ }^{1}$ \\ ${ }^{1}$ Spinal Cord Group, Institute of Biomedical and Life Sciences, University of Glasgow, Glasgow G12 8QQ, United Kingdom, and 'Department of Anatomy, \\ Hokkaido University School of Medicine, Sapporo 060-8638, Japan
}

Glutamate, the principal excitatory neurotransmitter in the spinal cord, acts primarily through AMPA receptors. Although all four AMPA subunits are expressed by spinal neurons, we know little about their distribution at glutamatergic synapses. We used an antigenunmasking technique to reveal the synaptic distribution of glutamate receptor (GluR) 1-4 subunits with confocal microscopy. After pepsin treatment, punctate staining was seen with antibodies against each subunit: GluR2-immunoreactive puncta were distributed throughout the gray matter, whereas GluR1-immunoreactive puncta were restricted to the dorsal horn and were most numerous in laminas I-II. Punctate staining for GluR3 and GluR4 was found in all laminas but was weak in superficial dorsal horn. Colocalization studies showed that GluR2 was present at virtually all (98\%) puncta that were GluR1, GluR3, or GluR4 immunoreactive and that most $(>90 \%)$ immunoreactive puncta in laminas IV, V, and IX showed GluR2, GluR3, and GluR4 immunoreactivity.

Evidence that these puncta represented synaptic receptors was obtained with electron microscopy and by examining the association of GluR2- and GluR1-immunoreactive puncta with glutamatergic boutons (identified with vesicular glutamate transporters or markers for unmyelinated afferents). The great majority (96\%) of these boutons were associated with GluR2-immunoreactive puncta. Our findings suggest that GluR2 is almost universally present at AMPA-containing synapses, whereas GluR1 is preferentially associated with primary afferent terminals.

We also found a substantial, rapid increase in staining for synaptic GluR1 subunits phosphorylated on the S845 residue in the ipsilateral dorsal horn after peripheral noxious stimulation. This finding demonstrates plastic changes, presumably contributing to central sensitization, at the synaptic level.

Key words: immunocytochemistry; VGLUT1; VGLUT2; CGRP; IB4; capsaicin

\section{Introduction}

Glutamate is the main excitatory neurotransmitter in the spinal cord and is used by primary afferents, excitatory interneurons, projection neurons, and some descending axons (Broman, 1994). Glutamate acts on ionotropic glutamate receptors (iGluRs) and metabotropic glutamate receptors, which are widely expressed by spinal neurons (Coggeshall and Carlton, 1997). iGluRs can be divided into three classes on the basis of their preference for AMPA, kainate, or NMDA. AMPA receptors mediate fast EPSPs in spinal neurons (Yoshimura and Jessell, 1990; Yoshimura and Nishi, 1992) and are responsible for transmission of nociceptive signals perceived as acute pain (Dickenson et al., 1997). AMPA

\footnotetext{
Received Dec. 24, 2003; revised May 4, 2004; accepted May 10, 2004.

This work was supported by the Biotechnology and Biological Sciences Research Council, Wellcome Trust, British Council, and Faculty of Medical and Health Sciences at the United Arab Emirates University. We thank R. Kerr, C. Watt, and M. McGill for expert technical assistance and Prof. D. J. Maxwell for helpful discussion and advice.

Correspondence should be addressed to Dr. A. J. Todd, Spinal Cord Group, West Medical Building, University of Glasgow, University Avenue, Glasgow G12 8QQ, UK. E-mail: a.todd@bio.gla.ac.uk.

DOI:10.1523/JNEUROSCI.1237-04.2004

Copyright $\odot 2004$ Society for Neuroscience $\quad$ 0270-6474/04/245766-12\$15.00/0
}

receptors have also been implicated in excitotoxicity and degeneration of motoneurons in amyotrophic lateral sclerosis (van Damme et al., 2002).

mRNAs for all four subunits of the AMPA receptor (GluR1-4) have been identified in the spinal cord (Furuyama et al., 1993; Henley et al., 1993; Tölle et al., 1993, 1995; Jakowec et al., 1995b; Shibata et al., 1999). Although conventional immunocytochemical studies have been performed to detect AMPA subunits (Tachibana et al., 1994; Jakowec et al., 1995a; Popratiloff et al., 1996, 1998; Morrison et al., 1998; Spike et al., 1998), it is unlikely that these revealed receptors at glutamatergic synapses, because these are thought to be inaccessible due to extensive cross-linking of the protein meshwork of the synaptic cleft and postsynaptic density that results from aldehyde fixation (Baude et al., 1995; Ottersen and Landsend, 1997; Fritschy et al., 1998; Watanabe et al., 1998). Postembedding immunogold-labeling has been used to investigate synaptic AMPA receptors in the spinal cord (Popratiloff et al., 1996, 1998; Morrison et al., 1998; Ragnarson et al., 2003); however, despite this, the pattern of AMPA subunit expression at individual synapses remains largely elusive. 
There are major differences between AMPA subunits in their physiology, pharmacology, and involvement in synaptic plasticity (Dingledine et al., 1999). For example, the subunits differ in their response to phosphorylation (Bredt and Nicoll, 2003), a process that is thought to contribute to central sensitization of dorsal horn neurons in chronic pain states (Sandkühler, 2000; Fang et al., 2003; Ji et al., 2003). In addition, absence of the GluR2 subunit results in $\mathrm{Ca}^{2+}$ permeability, which has been implicated in certain pathological conditions (Sorkin et al., 1999, 2001; Vandenberghe et al., 2001). Knowledge of the subunit composition at synapses in specific neuronal circuits is therefore of fundamental importance for our understanding of synaptic function and plasticity.

In this study, we examined synaptic AMPA subunits with confocal and electron microscopy by adopting a proteolytic antigenunmasking method that allows antibodies to gain access to synaptic receptors (Watanabe et al., 1998). We provide the first demonstration of the laminar distribution of all four AMPA subunits at synapses in the spinal cord, and for GluR1 and GluR2 subunits, we investigated their relationship to different types of glutamatergic axon. We also show that this method can be used in functional studies, because we were able to demonstrate phosphorylation of GluR1 at synapses in the superficial dorsal horn in response to noxious stimulation.

\section{Materials and Methods}

GluR antibodies. A rabbit antibody against the C-terminal amino acid residues 830-862 of mouse GluR3 (GenBank accession number $\mathrm{AB} 022342$ ) and a guinea pig antibody against residues $245-273$ of mouse GluR4 (GenBank accession number AB022913) were generated as described previously (Fukaya and Watanabe, 2000). Using the pGEX4T-2 plasmid vector (Amersham Biosciences, Bucks, UK), proteins were expressed as a glutathione S-transferase (GST) fusion protein and purified using glutathione-Sepharose 4B (Amersham Biosciences). After thrombin digestion, antigen polypeptides (R3C and $\mathrm{R} 4 \mathrm{~N}$ ) were separated from GST by reverse-phase HPLC. Purified polypeptides were injected into female rabbits and guinea pigs at intervals of 2 weeks. Antibodies for GluR3 (GluR3C) and GluR4 (GluR4N) were affinity-purified using GST fusion protein-coupled cyanogen bromide-activated Sepharose 4B (Amersham Biosciences).

To test the specificity of these antibodies, spinal cords of adult C57BL/6 mice were homogenized in $8-10$ volumes of ice-cold buffer containing $0.32 \mathrm{~m}$ sucrose, $1 \mathrm{~mm}$ EDTA, $1 \mathrm{~mm}$ EGTA, $10 \mathrm{~mm}$ Tris-HCl, $\mathrm{pH} 7.2$, and $0.4 \mathrm{~mm}$ phenylmethylsulfonyl fluoride (homogenization buffer) using a Potter homogenizer with 15 strokes at $800 \mathrm{rpm}$. To obtain a postsynaptic density (PSD) fraction, the homogenate was centrifuged at $1000 \times g$ for $10 \mathrm{~min}$ to remove nuclei and large debris. The supernatant was centrifuged at $10,000 \times g$ for $20 \mathrm{~min}$ to obtain a crude synaptosomal fraction and subsequently lysed hypo-osmotically and centrifuged at $25,000 \times g$ for $30 \mathrm{~min}$ to pellet a synaptosomal fraction. The pellet was suspended with homogenization buffer containing $0.5 \%$ Triton X-100 for $15 \mathrm{~min}$ and centrifuged at $111,000 \times g$ for $1 \mathrm{hr}$ to pellet a PSD fraction. The protein concentration was determined by Lowry's method. After SDS-PAGE, fractionated samples in the gel were electroblotted onto nitrocellulose membranes (BioTraceNT; Pall Gelman Laboratory, Ann Arbor, MI). Membranes were incubated with $5 \%$ skimmed milk in Trisbuffered saline (TBS) containing $0.1 \%$ Tween 20 (TBST), pH 7.5, for 1 $\mathrm{hr}$, followed by incubation with primary antibodies $(1 \mu \mathrm{g} / \mathrm{ml})$ in TBST for $2 \mathrm{hr}$. Immunoreaction was visualized with the ECL chemiluminescence detection system (Amersham Biosciences). For preabsorption experiments, peptides $(0.2 \mu \mathrm{g} / \mathrm{ml})$ were added to the primary antibodies. To check the cross-immunoreactivity of GluR3C antibody to the GluR2 subunit, a dot blot assay was performed using C-terminal peptides for GluR2 and GluR3 subunits (amino acid residues 826-858 of GluR2, R2C; 830-862 of GluR3, R3C). After the peptides were dotted onto nitrocellulose membranes, immunoreaction was performed as above.
The affinity-purified rabbit antibodies against GluR1 and GluR2 used in this study (Chemicon International, Harlow, UK) show no crossreactivity with other GluR subunits (specification of manufacturer). The mouse monoclonal anti-GluR2 (Chemicon; clone 6C4) has been extensively characterized and shown not to detect any other AMPA or kainate subunits (Vissavajjhala et al., 1996).

Animals for immunocytochemistry. Experiments were approved by the University of Glasgow Ethical Review Process Applications Panel and performed in accordance with the UK Animals (Scientific Procedures) Act 1986. Twelve adult male Wistar rats (220-390 gm; Harlan, Loughborough, UK) were deeply anesthetized with pentobarbitone $(300 \mathrm{mg}$, i.p.) and perfused transcardially with fixative containing $4 \%$ freshly depolymerized formaldehyde ( 10 rats) or $4 \%$ formaldehyde $/ 0.1 \%$ glutaraldehyde (two rats). Three additional rats (280-330 gm) were used to investigate phosphorylation of the GluR1 subunit in response to noxious stimulation. These were anesthetized with ketamine and xylazine (73.3 and $7.3 \mathrm{mg} / \mathrm{kg}$, i.p., respectively) and received an injection of $250 \mu \mathrm{g}$ of capsaicin (Sigma, Poole, UK; dissolved in $25 \mu$ l of $7 \%$ Tween 80 in saline) into the plantar surface of the left hindpaw. They were maintained under general anesthesia and perfused with $4 \%$ formaldehyde under terminal pentobarbitone anesthesia $10 \mathrm{~min}$ after the capsaicin injection.

Lumbar spinal cord segments from all animals were removed, stored in fixative for $8-24 \mathrm{hr}$, and cut into transverse $60 \mu \mathrm{m}$ Vibratome sections, which were immersed in 50\% ethanol for 30 min to enhance antibody penetration.

Immunofluorescent detection of GluR1-4. To expose AMPA receptor subunits at synaptic sites, sections were processed according to an antigen-unmasking method involving pepsin digestion (Watanabe et al., 1998). In some experiments, glutamatergic axons were identified with antibodies against the vesicular glutamate transporters VGLUT1 and VGLUT2, which are primarily associated with myelinated primary afferents and excitatory interneurons, respectively (Todd et al., 2003). Unmyelinated (C) primary afferents generally do not have detectable levels of these transporters (Todd et al., 2003), and we therefore identified peptidergic and nonpeptidergic $\mathrm{C}$ afferents with an antibody against calcitonin gene-related peptide (CGRP) and binding of Bandeiraea simplicifolia isolectin B4 (IB4), respectively. After pepsin treatment, staining for these axonal markers disappeared near the surfaces of the Vibratome section, where punctate staining for the GluRs was optimal. Detection of these compounds was therefore performed before pepsin treatment with the tyramide signal amplification (TSA) method, which resulted in deposition of covalently bound fluorophore that was resistant to proteolysis. Pepsin treatment was performed by incubating sections at $37^{\circ} \mathrm{C}$ for 30 min in PBS followed by $10 \mathrm{~min}$ in $0.2 \mathrm{M} \mathrm{HCl}$ containing $1 \mathrm{mg} / \mathrm{ml}$ pepsin (Dako, Glostrup, Denmark). For sections processed for confocal microscopy, the PBS contained $0.3 \%$ Triton X100.

To investigate the relationship between GluR1, GluR2, and various types of glutamatergic bouton, sections were incubated for $72 \mathrm{hr}$ at $4^{\circ} \mathrm{C}$ in one of the following: (1) guinea pig anti-VGLUT1 (Chemicon; 1:200,000 or 1:500,000), (2) guinea pig anti-VGLUT2 (Chemicon; 1:50,000), (3) a mixture of both guinea pig VGLUT antibodies (at the corresponding concentrations), (4) guinea pig anti-CGRP (Bachem, Merseyside, UK; $1: 100,000$ ), or (5) biotinylated IB4 (Sigma; $2 \mu \mathrm{g} / \mathrm{ml}$ ). They were then incubated for $2 \mathrm{hr}$ at room temperature in biotinylated donkey antiguinea pig IgG (Jackson ImmunoResearch, West Grove, PA; 1:500) (except for those treated with IB4) and processed with a TSA kit (tetramethylrhodamine; PerkinElmer Life Sciences, Boston, MA) according to the instructions of the manufacturer. Sections were rinsed, pepsin treated, and incubated for $24 \mathrm{hr}$ at $4^{\circ} \mathrm{C}$ in a mixture of rabbit anti-GluR1 (1:500) and mouse anti-GluR2 $(3.9 \mu \mathrm{g} / \mathrm{ml})$, followed by $2-24 \mathrm{hr}$ in species-specific donkey secondary antibodies: anti-mouse IgG conjugated to Alexa 488 (Molecular Probes, Eugene, OR; 1:500) and anti-rabbit IgG conjugated to Cyanine 5.18 (Cy5; Jackson ImmunoResearch; 1:100). They were mounted with anti-fade medium and stored at $-20^{\circ} \mathrm{C}$. Sections from three rats were processed with each of these antibody combinations.

We performed triple-immunofluorescence labeling to examine the relationship between GluR2, GluR3, and GluR4. Sections from three rats were pepsin treated and incubated for $72 \mathrm{hr}$ at $4^{\circ} \mathrm{C}$ in a mixture of mouse 
anti-GluR2 (3.9 $\mu \mathrm{g} / \mathrm{ml})$, rabbit anti-GluR3 (GluR3C) $(0.41 \mu \mathrm{g} / \mathrm{ml})$, and guinea pig anti-GluR4 (GluR4N) $(0.76 \mu \mathrm{g} / \mathrm{ml})$, followed by speciesspecific donkey secondary antibodies (anti-mouse and guinea pig IgG conjugated to Cy5 or Rhodamine Red, 1:100, Jackson ImmunoResearch; anti-rabbit IgG conjugated to Alexa 488, 1:500, Molecular Probes).

Preabsorption controls for the GluR3 and GluR4 antibodies were performed by adding R4N peptide to the GluR4 antibody and R2C or R3C peptide to the GluR3 antibody ( $10 \mu \mathrm{g} / \mathrm{ml}$ peptide added to $50 \mu \mathrm{g} / \mathrm{ml}$ antibody in each case) and then diluting the antibody to the concentrations above. To compare staining obtained with rabbit and mouse GluR2 antibodies, some sections were treated with pepsin and incubated in a mixture of these two primary antibodies, followed by appropriate fluorescent secondary antibodies.

To assess the effect of pepsin treatment, nonpepsin-treated sections were incubated in rabbit anti-GluR1 (1:500), mouse anti-GluR2 (3.9 $\mu \mathrm{g} / \mathrm{ml})$, rabbit anti-GluR3 $(0.41 \mu \mathrm{g} / \mathrm{ml})$, or guinea pig anti-GluR4 $(0.76$ $\mu \mathrm{g} / \mathrm{ml})$, followed by fluorescent secondary antibodies.

Confocal microscopy and analysis of GluR1-4. Sections reacted with antibodies against GluR2, GluR3, and GluR4 were analyzed to determine the extent of colocalization of these subunits in immunoreactive puncta. One section from each of three animals was scanned through a $60 \times$ oil-immersion lens with a Bio-Rad (Hemel Hempstead, UK) Radiance 2100 confocal laser-scanning microscope. Z-series were scanned at 0.3 $\mu \mathrm{m}$ z-separation through the top $10-15 \mu \mathrm{m}$ of the section, and five regions were analyzed in each case: laminas I/II, III, IV, V, and IX. Confocal image stacks were analyzed with MetaMorph software (Universal Imaging, Downington, PA). The three-color channels were merged and combined into a monochrome image, so that the subunit combination in each punctum could not be determined. One hundred immunoreactive puncta were selected from each region in each animal. To avoid bias, a 100-square grid was placed on the image, and the punctum closest to bottom right corner of each grid square was selected. Selected puncta were then examined in the three-color image stack to determine which types of subunit immunoreactivity they expressed.

From each of three rats, a single section reacted with anti-GluR1 and anti-GluR2, together with anti-VGLUT1, anti-VGLUT2, anti-CGRP, or biotinylated IB4, was analyzed. These sections were scanned through a $60 \times$ oil-immersion lens as described above. VGLUT1- and VGLUT2labeled boutons were analyzed in laminas I, II, III, IV, V, and IX. Most VGLUT1 terminals in the inner half of lamina II (IIi) belong to myelinated primary afferents, whereas those in outer lamina II (IIo) are not of primary afferent origin (Todd et al., 2003). We therefore analyzed laminas IIi and IIo separately for both VGLUTs. CGRP- and IB4-labeled axons were analyzed in the regions in which they were most numerous: laminas I/IIo (CGRP) and lamina II (IB4). Confocal image stacks were viewed with MetaMorph such that only the axonal marker was visible, and 100 labeled axons were randomly selected from each region in each animal. The other two confocal channels were then viewed, and the number of GluR1- and/or GluR2-immunoreactive puncta in contact with each bouton was determined.

VGLUT1 and VGLUT2 are thought to label the great majority of glutamatergic terminals in the spinal cord, apart from those belonging to $\mathrm{C}$ afferents. To investigate the proportion of GluR2 puncta that was in contact with glutamatergic terminals, and thus likely to represent synaptic receptors, we therefore analyzed sections reacted with antibodies against both transporters and GluR2. One section from each of three animals was scanned through a $60 \times$ oil-immersion lens, and three regions were analyzed in each case: laminas I/II, III/IV, and IX. Image stacks were initially viewed such that only GluR2 staining was visible, and 100 immunoreactive puncta were selected from each region in each animal using a grid to avoid bias. The VGLUT staining was then examined, and the proportion of selected puncta in contact with a VGLUTimmunoreactive bouton was determined.

Electron microscopy. Although AMPA subunits have been found in primary afferent terminals in the spinal cord (Lu et al., 2002), we did not see GluR immunostaining that appeared to be located inside primary afferent boutons after pepsin treatment (see Results). However, we could not rule out the possibility that some of the punctate labeling apposed to primary afferent terminals corresponded to receptors in the presynaptic membrane. We therefore performed electron microscopy to confirm that the punctate labeling seen with GluR1 and GluR2 antibodies represented postsynaptic receptors. Sections from the two rats fixed with formaldehyde/ glutaraldehyde were treated with $1 \%$ sodium borohydride for $30 \mathrm{~min}$ followed by pepsin and incubated in rabbit anti-GluR1 $(1: 2,000)$ or rabbit anti-GluR2 (1:500) for $72 \mathrm{hr}$ and in biotinylated donkey anti-rabbit IgG (Jackson ImmunoResearch; 1:500) followed by Extravidin-peroxidase conjugate (Sigma; 1:1000), each for $24 \mathrm{hr}$. Peroxidase was revealed with 3,3'diaminobenzidine, and the sections were osmicated, dehydrated in acetone, and flat-embedded in Durcupan. Ultrathin sections were cut onto Formvarcoated single-slot grids, stained with lead citrate, and viewed with a Philips CM100 electron microscope. For comparison, nonpepsin-treated Vibratome sections were processed in parallel.

For the pepsin-treated material, one ultrathin section from each animal reacted with GluR1 and one reacted with GluR2 were examined. The region corresponding to laminas I-III was systematically scanned until 50 immunoreactive synapses had been identified on each section, and the relationship of reaction product to synaptic membranes was noted in each case. We also noted any immunoreactive vesicle-containing profiles. Ultrathin sections from tissue reacted with GluR1 or GluR2 without pepsin treatment were then viewed (one from each rat for each antibody), and an area equivalent to that scanned in the pepsin-treated sections was examined.

Detection of phosphorylated GluR1 subunits. To determine whether immunocytochemically detectable changes involving synaptic AMPA receptors occurred after noxious stimulation, immunolabeling was performed to reveal GluR1 subunits phosphorylated at the Serine 845 site (GluR1-pS845) (Roche et al., 1996) on sections from three rats that received injections of capsaicin into the left hindpaw 10 min before perfusion. Pepsin-treated L4 sections were incubated in a mixture of rabbit anti-GluR1-pS845 (Covance, Berkeley, CA; $0.5 \mu \mathrm{g} / \mathrm{ml}$ ) and mouse antiGluR2 $(3.9 \mu \mathrm{g} / \mathrm{ml})$ for $48 \mathrm{hr}$, followed by donkey secondary antibodies (anti-mouse-Alexa 488, 1:500, Molecular Probes; biotinylated antirabbit, 1:500, Jackson ImmunoResearch) for $2 \mathrm{hr}$. GluR1-pS845 was revealed with the TSA kit. The antibody against GluR2 was used to demonstrate that punctate staining seen with the GluR1-pS845 antibody corresponded to AMPA-containing synapses, because GluR2 was found in virtually all puncta that contained GluR1 (see Results).

One section from each rat was scanned through a $60 \times$ oil-immersion lens with the confocal microscope. From these sections, three adjacent overlapping fields (each $155 \times 155 \mu \mathrm{m}$ ) covering the medial half of laminas I and II of each dorsal horn were scanned sequentially at $1 \mu \mathrm{m}$ z-separation to reveal GluR1-pS845 and GluR2. The medial half of the superficial dorsal horn was analyzed because nociceptive primary afferents from the hindpaw terminate in this area. For each dorsal horn, the three image stacks were stitched together with Adobe Photoshop 7.0 (Adobe Systems, San Jose, CA) to produce a single optical section that covered the medial half of the dorsal horn, and the area corresponding to laminas I and II was outlined for subsequent analysis. The red channel (corresponding to GluR1-pS845) was switched off while this was performed to avoid bias in the selection of the optical section or the area that was to be analyzed. GluR1-pS845 immunoreactivity was analyzed in each of the optical sections by setting a threshold for pixel luminance value that excluded most of the "basal" immunostaining seen in the contralateral dorsal horn. Puncta in each dorsal horn that had at least one pixel exceeding this threshold value were identified and counted, and the presence or absence of GluR2 immunostaining in these puncta was determined.

The GluR1-pS845 antibody was raised against a synthetic phosphopeptide corresponding to amino acids surrounding the Ser845 residue of the rat GluR1 subunit and purified by sequential chromatography on protein A and phospho- and dephospho-peptide affinity columns. On Western blots of rat hippocampal homogenate, the antibody labels a single band corresponding to a molecular weight of $\sim 100 \mathrm{kDa}$ (specification of the manufacturer). Preabsorbtion controls for immunocytochemistry were performed by adding the phosphopeptide used to raise the antibody or the corresponding dephosphopeptide $(0.1 \mu \mathrm{g} / \mathrm{ml}$ in each case) to the antibody $24 \mathrm{hr}$ before use. 

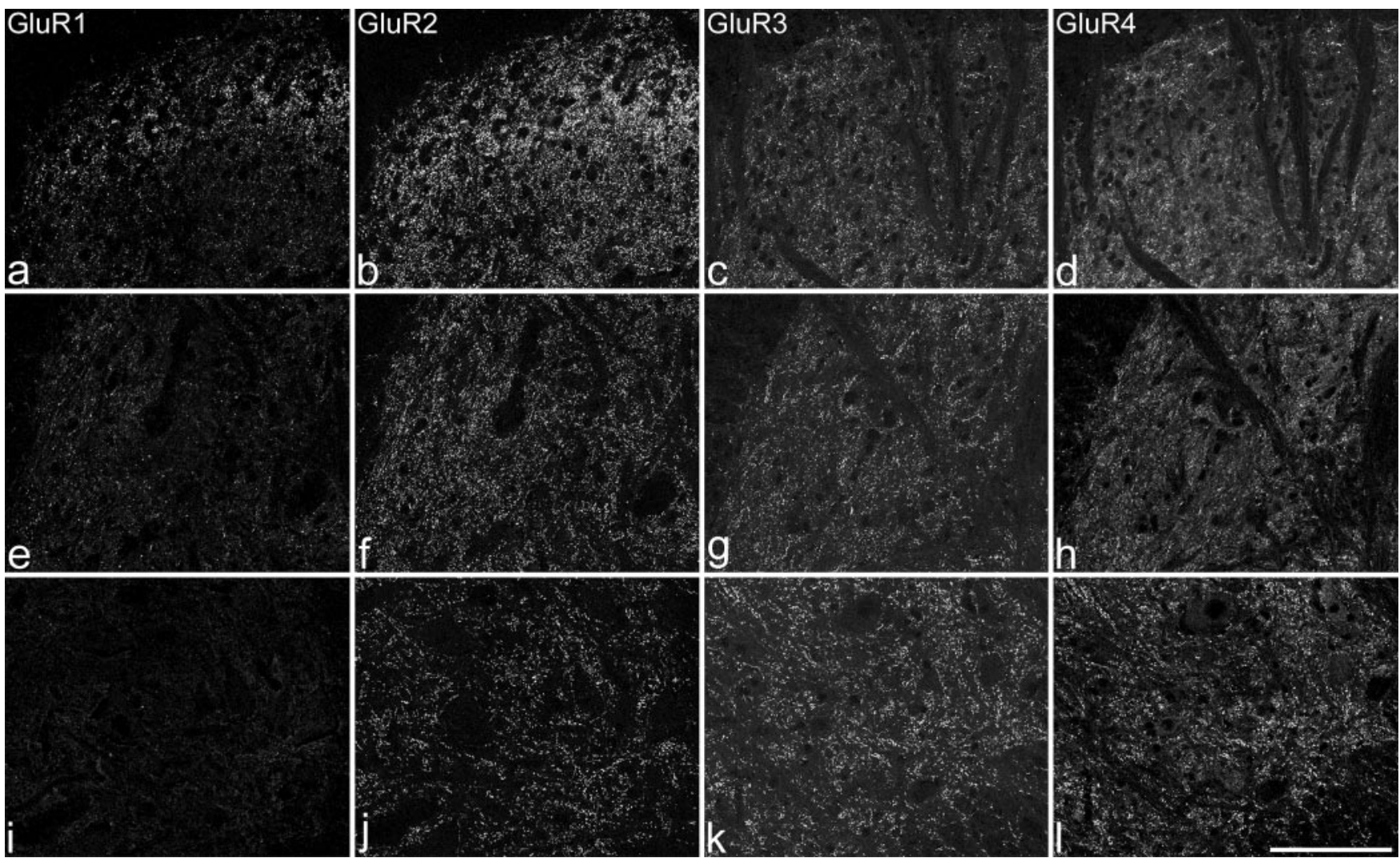

Figure 1. Immunostaining for GluR1-4 in the spinal cord after pepsin treatment. $a$ - $d$ show the medial part of the superficial dorsal horn (corresponding to laminas I-III). e- $h$ include the medial part of laminas IV and V. $i$-/are from lamina IX. GluR1-immunoreactive puncta are numerous in lamina II, present at lower density in other parts of the dorsal horn, and are virtually absent in lamina IX. GluR2-immunoreactive puncta are present in all parts of the dorsal horn, but the labeling is strongest in lamina II. Punctate labeling with both GluR3 and GluR4 antibodies is seen throughout the gray matter but is least dense in the superficial dorsal horn. Images of GluR1 and GluR2 are taken from one section, and those for GluR3 and GluR4 are taken from another. Each image was obtained from a projection of three optical sections at $0.5 \mu \mathrm{m}$ z-separation. Scale bar, $100 \mu \mathrm{m}$.

\section{Results}

GluR3 and GluR4 antibodies

The sequence used to generate the GluR3 antibody has a high level of homology with the corresponding part of the GluR2 subunit, and we therefore investigated whether this antibody crossreacted with GluR2. On dot blots, the GluR3 antibody detected the $\mathrm{R} 3 \mathrm{C}$ but not the $\mathrm{R} 2 \mathrm{C}$ peptide, indicating that it did not crossreact with the C-terminal portion of the GluR2 subunit. In Western blots of the PSD fraction from mouse spinal cord, the GluR3 and GluR4 antibodies each detected a single protein band corresponding to a molecular weight of $\sim 98 \mathrm{kDa}$. Staining with the GluR3 antibody was blocked by preabsorption with R3C but not R2C peptide, and the GluR4 staining was blocked with the R4N peptide. On sections of pepsin-treated spinal cord, punctate staining with GluR3 antibody was blocked by preabsorption with R3C but not $\mathrm{R} 2 \mathrm{C}$ peptide, whereas that with GluR4 antibody was blocked with R4N peptide. Characterization data for these antibodies is shown in supplemental Figure 1 (available at www.jneurosci.org).

\section{General appearance of immunofluorescence with GluR1-4 antibodies after antigen unmasking}

On pepsin-treated spinal cord sections, punctate staining was seen near the surface of the section (superficial 10-15 $\mu \mathrm{m}$ ) with each GluR antibody (Fig. 1). This became weaker deeper in the section, and for the GluR2 antibodies was replaced by cell body labeling identical to that reported without pepsin treatment (Popratiloff et al., 1996, 1998). The loss of cytoplasmic labeling suggests that extrasynaptic receptors are damaged during proteo- lytic treatment, whereas synaptic receptors are presumably protected by the surrounding protein meshwork. The rabbit and mouse GluR2 antibodies stained identical structures. Because punctate staining was seen with antibodies directed against both C-terminal (intracellular) (GluR1, GluR3, polyclonal GluR2) and N-terminal (extracellular) (GluR4, monoclonal GluR2) epitopes, proteolytic digestion presumably allows access to both postsynaptic density and synaptic cleft. Lu et al. (2002) found that after weak fixation, GluR2/3, GluR2/4, and GluR4 antibodies labeled central terminals of primary afferents in the dorsal horn. In pepsin-treated tissue viewed with confocal microscopy, we did not see a similar staining pattern with any of the GluR antibodies used in this study, suggesting that epitopes on presynaptic receptors are either damaged or remain inaccessible after pepsin treatment.

\section{Laminar distribution of AMPA subunits}

Previous immunohistochemical and in situ hybridization studies have suggested that GluR1 and GluR2 subunits are present throughout the dorsal horn, with highest levels in laminas I and II, that GluR2 is also present in the ventral horn, and that GluR3 and GluR4 are highly expressed in ventral horn, with moderate levels in deep dorsal horn and limited expression in the superficial laminas (Furuyama et al., 1993; Tölle et al., 1993; Tachibana et al., 1994; Jakowec et al., 1995a,b; Harris et al., 1996; Popratiloff et al., 1996, 1998; Morrison et al., 1998; Spike et al., 1998; Engelman et al., 1999; Shibata et al., 1999). Our findings after pepsin treatment are consistent with these reports (Fig. 1). GluR1 
showed the most restricted distribution, with immunoreactive puncta being frequent in lamina II, present at lower density in other dorsal horn laminas but rarely seen in the ventral horn. Numerous GluR2-immunoreactive puncta were present throughout the gray matter, with the strongest labeling in laminas I-II. GluR3- and GluR4-immunoreactive puncta were densely distributed throughout the ventral horn and laminas III-VI, with much weaker labeling in laminas I and II, although a few strongly labeled puncta were seen in this region, particularly in lamina I. It has been reported that motoneurons express GluR1 (PellegriniGiampietro et al., 1994; Virgo et al., 1996; Temkin et al., 1997; Williams et al., 1997; Bar-Peled et al., 1999; Shibata et al., 1999) or lack GluR2 subunits (Williams et al., 1997; Bar-Peled et al., 1999; Del Caño et al., 1999; Shaw et al., 1999). Our results do not support these suggestions, because we found that in lamina IX, there was virtually no punctate staining for GluR1, whereas GluR2 was expressed at virtually all puncta that contained any of the AMPA subunits (see below).

In nonpepsin-treated sections, labeling of cell bodies and small profiles that resembled dendrites was seen with GluR1 and GluR2 antibodies. Numerous GluR2immunoreactive cell bodies were observed throughout laminas I-III, whereas scattered GluR1-labeled cell bodies were present primarily in laminas I-II. However, the immunofluorescent labeling with these antibodies in sections that had not undergone pepsin treatment was much weaker than that in pepsin-treated sections and puncta of the type seen after pepsin treatment were not visible (supplemental Fig. 2, available at www.jneurosci.org). The GluR3 and GluR4 antibodies did not stain cell bodies or give punctate labeling in the absence of pepsin treatment. This suggests that conventional immunocytochemistry without antigen unmasking does not give significant labeling of synaptic AMPA receptors.

\section{Colocalization of AMPA subunits}

A specific question addressed in this part of the study was whether any AMPA-containing glutamatergic synapses lacked GluR2 subunits and would therefore have exclusively $\mathrm{Ca}^{2+}$-permeable AMPA receptors. We found that virtually all GluR1immunoreactive puncta throughout the dorsal horn were also GluR2 immunoreactive (Fig. 2a-c), although the relative intensity of labeling for the two subunits varied considerably between puncta. The extent of colocalization of these two subunits was investigated in the analysis of different types of glutamatergic boutons (see below). Colocalization of GluR2, GluR3, and GluR4 was examined in triple-labeled sections (Fig. $2 d-o$; Table 1). There was extensive colocalization of these subunits in all parts of

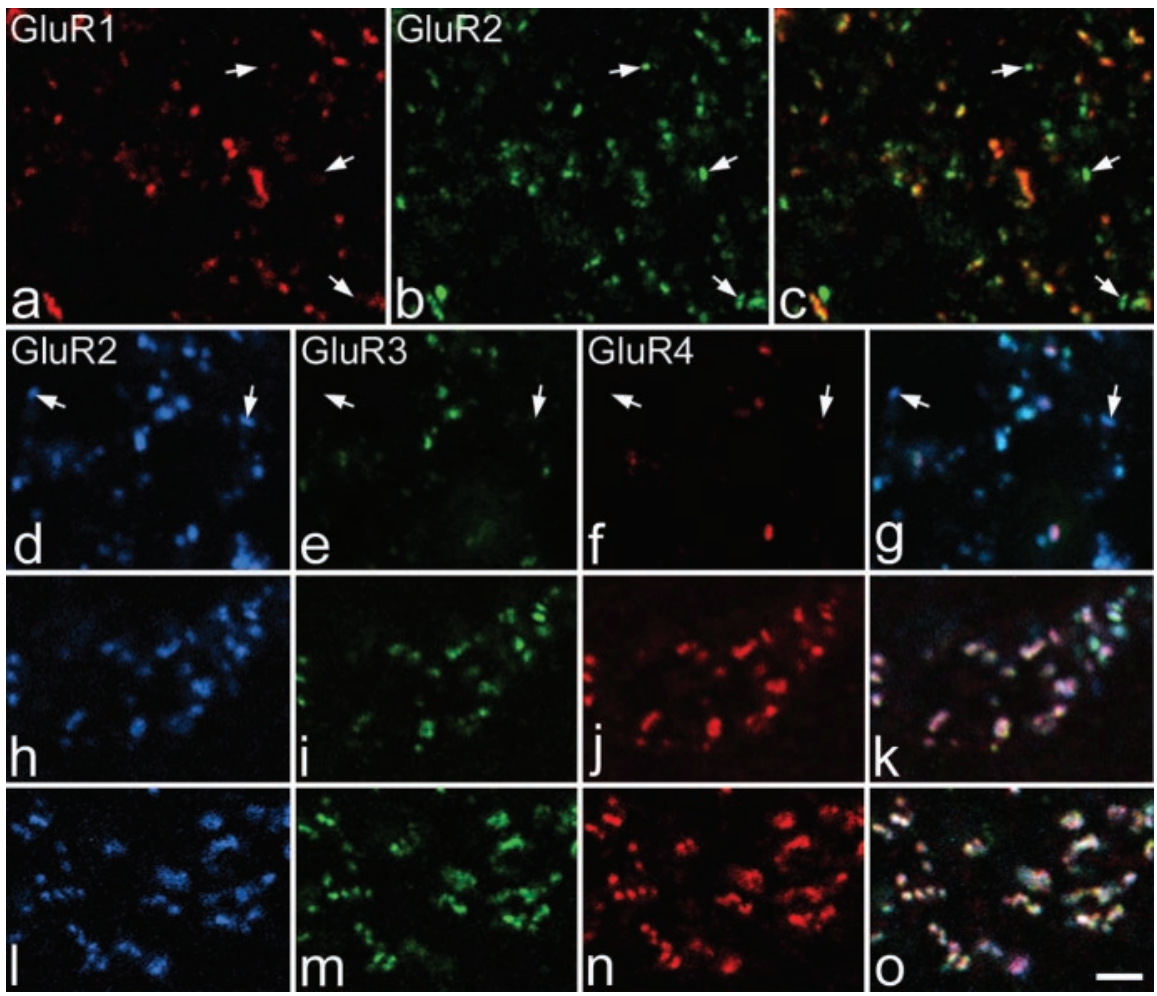

Figure 2. Colocalization of AMPA subunits. a-c show the same field from lamina II scanned to reveal GluR1 (red) and GluR2 (green). Note that all of the GluR1-immunoreactive puncta are also labeled with the GluR2 antibody, and that some GluR2immunoreactive puncta are not stained with the GluR1 antibody ( 3 of these are indicated with arrows). $d$-o show the relationship

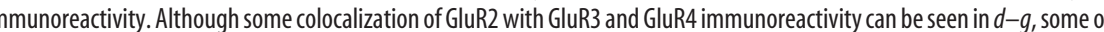
the puncta are only labeled with the GluR2 antibody ( 2 are indicated with arrows). All images show single optical sections. Scale

Table 1. Colocalization of GluR2, GluR3, and GluR4

\begin{tabular}{|c|c|c|c|c|c|c|c|c|}
\hline \multirow[b]{2}{*}{ Lamina } & \multicolumn{8}{|c|}{ Subunit combination } \\
\hline & $2 / 3 / 4$ & $2 / 3$ & $2 / 4$ & $3 / 4$ & 2 & 3 & 4 & GluR2 + (\%) \\
\hline$|/| \mid$ & $\begin{array}{l}36 \\
(31-39)\end{array}$ & $\begin{array}{l}32.7 \\
(28-35)\end{array}$ & $\begin{array}{l}7.3 \\
(2-10)\end{array}$ & $\begin{array}{l}1 \\
(0-2)\end{array}$ & $\begin{array}{l}22.3 \\
(22-23)\end{array}$ & $\begin{array}{l}0.7 \\
(0-1)\end{array}$ & 0 & 98.3 \\
\hline III & $\begin{array}{l}82 \\
(77-89)\end{array}$ & $\begin{array}{c}6.7 \\
(4-9)\end{array}$ & $\begin{array}{l}6.3 \\
(4-9)\end{array}$ & $\begin{array}{l}1.3 \\
(0-3)\end{array}$ & $\begin{array}{c}3.3 \\
(1-8)\end{array}$ & $\begin{array}{l}0.3 \\
(0-1)\end{array}$ & 0 & 98.3 \\
\hline IV & $\begin{array}{l}92 \\
(91-93)\end{array}$ & $\begin{array}{c}0.7 \\
(0-1)\end{array}$ & $\begin{array}{l}5 \\
(3-7)\end{array}$ & 0 & $\begin{array}{c}0.7 \\
(0-1)\end{array}$ & $\begin{array}{l}1.3 \\
(1-3)\end{array}$ & $\begin{array}{l}0.3 \\
(0-1)\end{array}$ & 98.4 \\
\hline V & $\begin{array}{l}94.3 \\
(92-96)\end{array}$ & $\begin{array}{c}2 \\
(0-3)\end{array}$ & $\begin{array}{l}2 \\
(1-3)\end{array}$ & $\begin{array}{l}0.3 \\
(0-1)\end{array}$ & $\begin{array}{c}0.3 \\
(0-1)\end{array}$ & $\begin{array}{l}0.7 \\
(0-1)\end{array}$ & $\begin{array}{l}0.3 \\
(0-1)\end{array}$ & 98.6 \\
\hline IX & $\begin{array}{l}96 \\
(95-98)\end{array}$ & 0 & $\begin{array}{l}1.3 \\
(1-3)\end{array}$ & $\begin{array}{l}1.3 \\
(0-2)\end{array}$ & $\begin{array}{c}0.7 \\
(0-2)\end{array}$ & $\begin{array}{l}0.7 \\
(0-1)\end{array}$ & 0 & 98 \\
\hline
\end{tabular}

Mean numbers of puncta showing different patterns of colocalization of immunostaining for GluR2, GluR3, and GluR4. One hundred immunoreactive puncta were selected from each region in each of three rats. Ranges are given in parentheses.

the gray matter ventral to lamina III, with most immunoreactive puncta being triple labeled. The relationship was analyzed quantitatively in laminas I/II, III-V, and IX (Table 1). In laminas IV, V, and IX, the great majority ( $>90 \%$ ) of labeled puncta were immunoreactive with all three antibodies. The proportions of puncta that were triple labeled in lamina III and laminas I-II were 82 and $36 \%$, respectively. Between 98 and $99 \%$ of the puncta that were analyzed showed GluR2 immunoreactivity in all areas. The relative intensity of labeling for the three subunits varied between puncta (Fig. 2d-o). Labeling of puncta with the GluR3 and GluR4 antibodies was generally much weaker in laminas I-II than in other laminas, although a few puncta with strong GluR3 or 
GluR4 immunoreactivity were seen here (Fig. $2 d-g$ ). In contrast, the intensity of GluR2 immunoreactivity in individual puncta was generally higher in laminas I and II than in other laminas.

\section{Relationship of GluR1 and GluR2 to glutamatergic axons}

Detection of VGLUT1, VGLUT2, and CGRP immunoreactivity and IB4 binding with the TSA method before pepsin treatment resulted in labeling patterns identical to those reported previously for these markers in the rat spinal cord (Sakamoto et al., 1999; Varoqui et al., 2002; Todd et al., 2003). This shows that the TSA reaction can be used to preserve immunostaining for labile epitopes before antigen unmasking with pepsin. More than $90 \%$ of the labeled boutons in each of these populations were in contact with one or more GluR2-immunoreactive puncta (Figs. 3-5; Table 2), and of the 4800 glutamatergic boutons analyzed in this part of the study, 96.2\% had at least one contact.

In all regions examined, each VGLUT1-immunoreactive bouton was generally associated with more than one GluR2 punctum (Table 2). In many cases, particularly in laminas IIi and III, clusters of GluR2 puncta were seen surrounding VGLUT1immunoreactive boutons with an appearance that was consistent with a glomerular arrangement (Fig. $3 a-c$ ). In laminas IIi and III, the mean numbers of GluR2 puncta associated with each VGLUT1 bouton were 4.2 and 3.7, respectively, whereas for lamina IX, this figure was 5.5 (Fig. 3, Table 2). The mean numbers of GluR2 puncta associated with VGLUT1 boutons in the other laminas analyzed varied from 1.9 to 2.8 (Table 2). VGLUT2 boutons were associated with significantly fewer GluR2 puncta (Fig. 4), with the mean number of puncta per bouton varying from 1.4 to 1.9 in different laminas (Table 2) (general linear model with Tukey's post hoc test; $p<0.05$ for lamina I; $p<0.001$ for all other regions examined). For IB4-labeled axons in lamina II, the mean number of GluR2 puncta per bouton was 4.8 (Fig. $5 a-c$ ), whereas for CGRP-immunoreactive boutons in laminas I-IIo, the corresponding value was 2.6 (Fig. $5 d-f$ ) (Table 3 ).

Many GluR1-immunoreactive puncta were observed in the dorsal horn, and virtually all of these were also GluR2 immunoreactive (Figs. $3-5$, Table 2). Only $18(0.14 \%)$ of the 12,493 puncta identified on the 4800 boutons examined in this part of the study showed GluR1 but not GluR2 immunoreactivity. Although puncta that were both GluR1 and GluR2 immunoreactive were associated with each type of axonal bouton in the dorsal horn, this arrangement was not uniform. In laminas I and II, between 30 and $40 \%$ of the GluR2 puncta associated with VGLUT1 boutons was also GluR1 immunoreactive, whereas for VGLUT2 boutons, the proportion was much lower, between 13 and $17 \%$ (Table 2). Similarly in laminas III and IV, 19\% of puncta adjacent to VGLUT1 boutons was GluR1 immunoreactive, compared with $2-4 \%$ for VGLUT2 boutons (Table 2). The proportion of puncta showing both GluR1 and GluR2 immunoreactivity was significantly higher for VGLUT1 than for VGLUT2 boutons in each of laminas I-IV (general linear model with Tukey's post hoc test; $p<0.05$ for laminas I and III; $p<0.01$ for laminas IIo, Iii, and IV). For the IB4 and CGRP boutons, the proportions of GluR2 puncta that were also GluR1 immunoreactive were 34 and $31 \%$, respectively (Table 3 ), and these values were significantly different from those for VGLUT2 boutons in the corresponding laminas (general linear model with Tukey's post hoc test; $p<$ $0.05)$. These results suggest that GluR1-containing synapses are preferentially associated with primary afferent terminals.

To determine whether a significant proportion of the GluR2immunoreactive puncta seen after pepsin treatment represented nonsynaptic (e.g., cytoplasmic) receptors, we analyzed sections
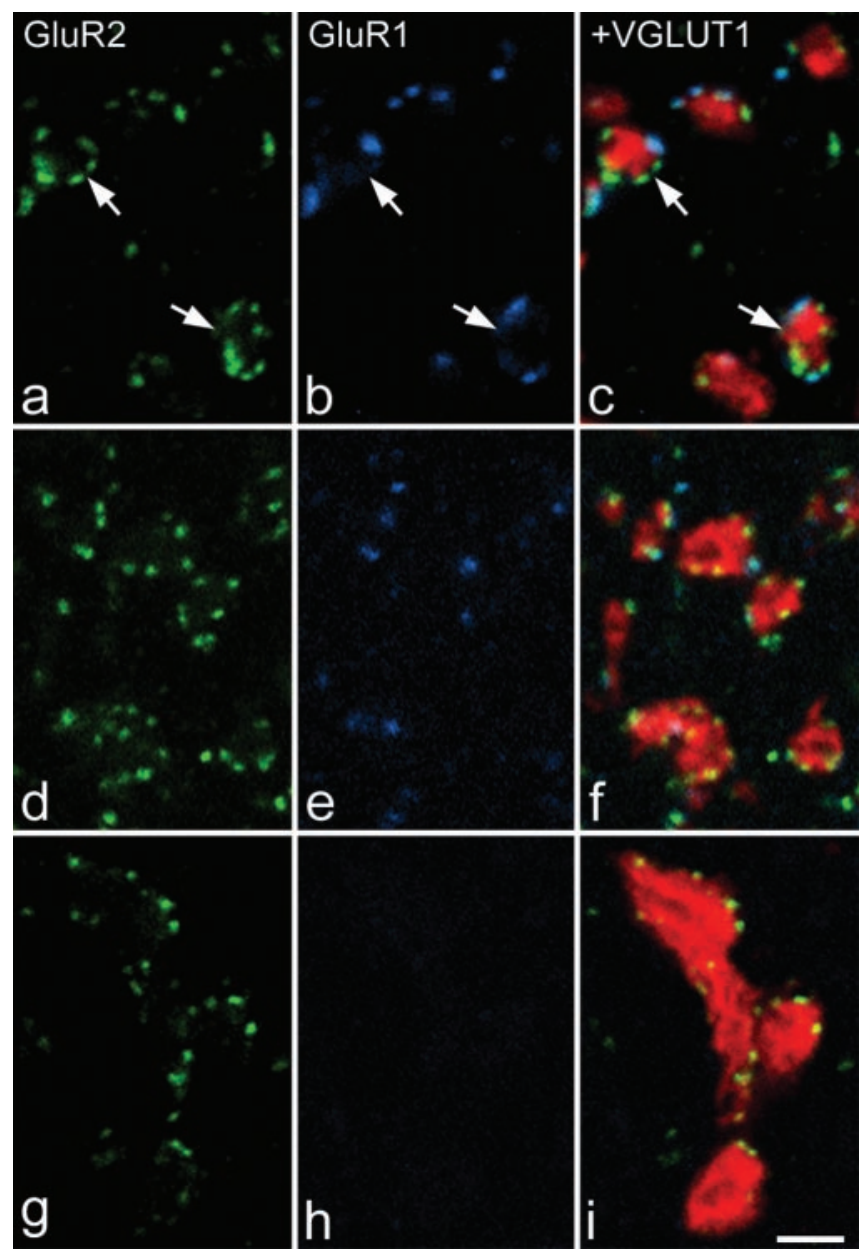

Figure 3. GluR1 and GluR2 puncta associated with VGLUT1-immunoreactive boutons. In each case, GluR2 immunostaining is shown in green in the left panel, GluR1 in blue in the center panel, and these have been merged with VGLUT1 staining (red) in the right panel. $a$-c are from lamina Ili. $d-f$ are from lamina IV. $g-i$ are from lamina IX. In all cases, the VGLUT1 boutons contact GluR2-immunoreactive puncta. In the dorsal horn, some of these puncta are also GluR1 immunoreactive. In lamina Ili, these puncta often surround the VGLUT1 bouton, with an appearance that is suggestive of a glomerular arrangement (arrows). Note that occasional overlap between GluR-immunoreactive puncta and axonal staining is likely to be attributable to either invagination of a dendrite into a bouton or obliquity of the synapse with respect to the plane of section. All images were obtained from single optical sections. Scale bar, $2 \mu \mathrm{m}$.

reacted with GluR2, VGLUT1, and VGLUT2 antibodies. Between 49 and $60 \%$ (mean, 55.7) of GluR2 puncta in laminas I-II were associated with a bouton that was VGLUT1 or VGLUT2 immunoreactive. The corresponding values for laminas III-IV were $84-89 \%$ (mean, 86.3 ), and for lamina IX they were $83-87 \%$ (mean, 84.7). This suggests that for the deep dorsal horn and ventral horn, at least $85 \%$ of puncta are associated with glutamatergic synapses, and because VGLUT1 and VGLUT2 antibodies do not stain all glutamatergic axons, this figure is probably an underestimate. Because boutons belonging to $\mathrm{C}$ fibers are often not labeled with VGLUT1 or VGLUT2 antibodies (Todd et al., 2003), these are likely to account for many of the GluR2 puncta that were not in contact with a VGLUT1- or VGLUT2-containing bouton in laminas I and II (Fig. 5).

\section{Electron microscopy}

Although the ultrastructure was compromised by pepsin treatment, it was frequently possible to identify immunoreactive synapses with both GluR1 and GluR2 antibodies, and in all cases, 


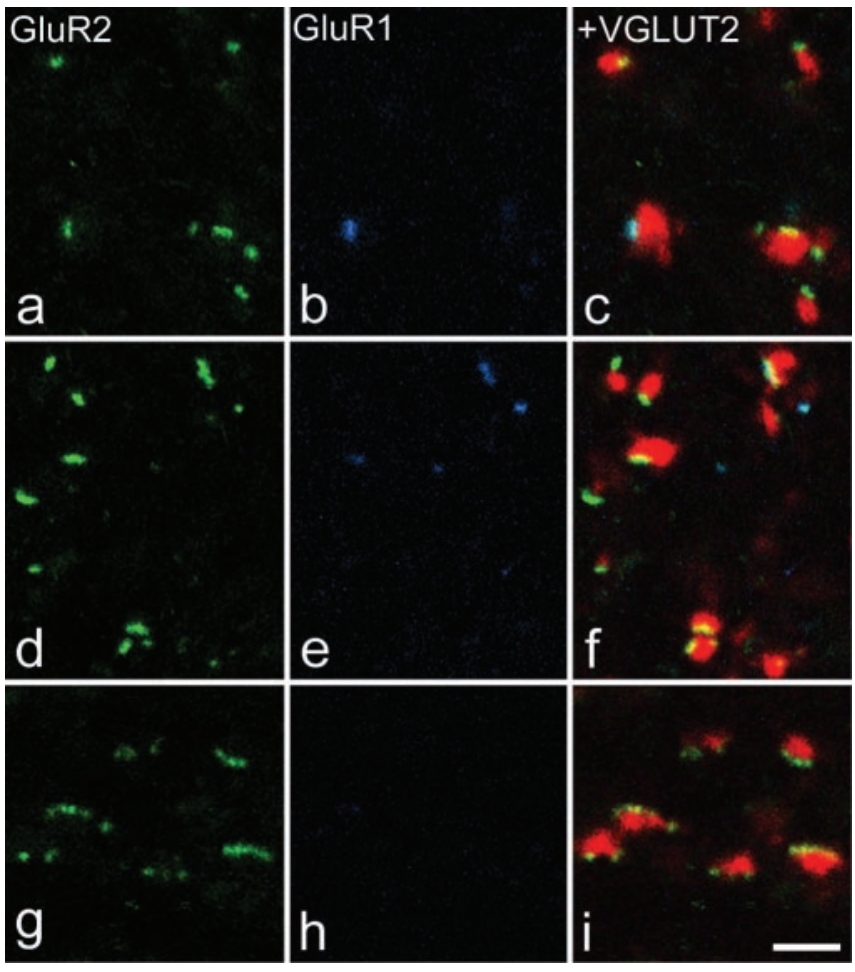

Figure 4. GluR1 and GluR2 puncta associated with VGLUT2-immunoreactive boutons. In each case, GluR2 immunostaining is shown in green in the left panel, GluR1 in blue in the center panel, and these have been merged with VGLUT2 staining (red) in the right panel. $a$-c are from lamina I. $d-f$ are from lamina V. $g-i$ are from lamina IX. Note that VGLUT2 boutons are associated with few GluR2-immunoreactive puncta and that some of the puncta in contact with these boutons in the dorsal horn are also GluR1 immunoreactive. All images were obtained from single optical sections. Scale bar, $2 \mu \mathrm{m}$.

reaction product was restricted to the postsynaptic profile and associated with the postsynaptic density (Fig. 6). This is consistent with a cytoplasmic location for the $\mathrm{C}$ terminal of these subunits and confirms that puncta seen adjacent to glutamatergic boutons with confocal microscopy correspond to postsynaptic receptors.

With both antibodies, reaction product was occasionally seen in cell bodies, nonsynaptic regions of dendrites, and vesiclecontaining profiles. While scanning an area that contained 50 immunoreactive synapses on each section, we found three immunoreactive vesicle-containing profiles in each of the two GluR1 sections analyzed and one in one of the GluR2 sections. One of these profiles (that was found in the GluR2 section) was presynaptic at an asymmetrical synapse and was therefore presumably an axonal bouton. The reaction product in this profile was not associated with the presynaptic membrane but was located in the center of the bouton. The other six vesicle-containing profiles did not form synapses in these sections, and it was not possible to determine whether these were axons or vesiclecontaining dendrites. In formaldehyde-fixed tissue treated with pepsin and viewed with confocal microscopy, we never saw GluR1-immunoreactive cell bodies, and GluR2-immunoreactive cell bodies were only seen in deeper parts of the section. The finding of occasional GluR1- and GluR2-immunoreactive cell bodies near the surface of pepsin-treated sections processed for electron microscopy suggests that glutaraldehyde can protect nonsynaptic AMPA receptor subunits from loss during pepsin digestion. If glutaraldehyde also preserves some presynaptic re-

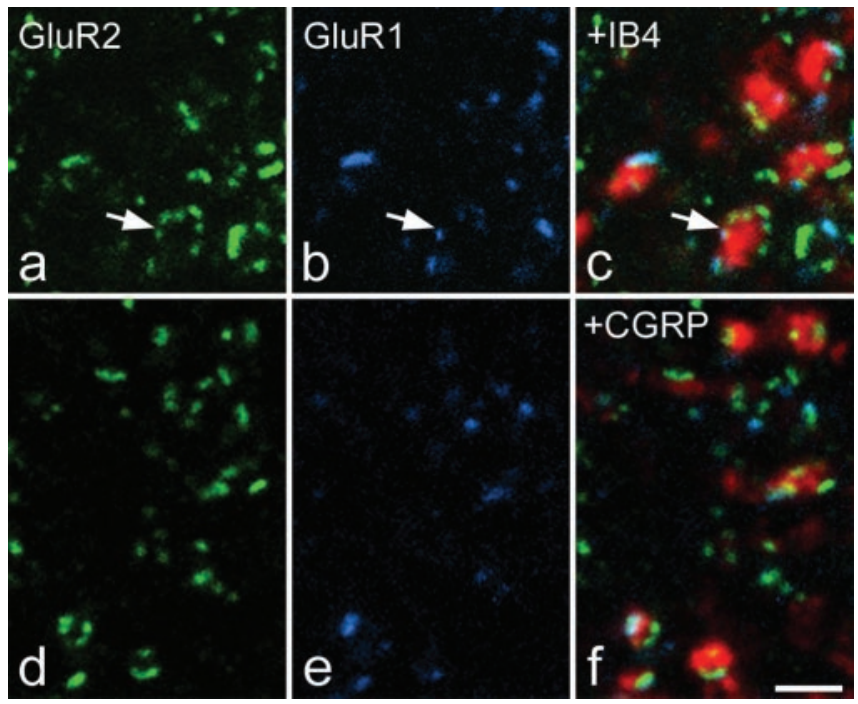

Figure 5. GluR1 and GluR2 puncta associated with terminals of fine afferents in lamina II. a-c show GluR2 (green) and GluR1 (blue) immunoreactivity, together with binding of IB4 (red). The IB4-labeled boutons are in contact with GluR2-immunoreactive puncta, some of which are also GluR1 immunoreactive. In many cases, the IB4 boutons were surrounded by immunoreactive puncta with an appearance that was suggestive of a glomerular arrangement (arrow). $d-f$ GluR2 (green), GluR1 (blue), and CGRP (red) immunoreactivity. The CGRP boutons are associated with GluR2-immunoreactive puncta, some of which are also GluR1 immunoreactive. All images were obtained from single optical sections. Scale bar, $2 \mu \mathrm{m}$.

ceptors during pepsin treatment, this may account for some of the labeled vesicle-containing profiles seen with EM.

Numerous synapses were seen in the sections that had been reacted with GluR1 and GluR2 antibodies without pepsin treatment; however, none of these was immunoreactive with either antibody. This is consistent with our failure to see punctate staining for GluR1 and GluR2 with confocal microscopy on sections that had not been pepsin treated.

Our findings with confocal and electron microscopy, taken together with studies that have revealed presynaptic receptors on lightly fixed material (Lu et al., 2002), suggest that receptor subunits at different subcellular locations are affected differently by fixation and pepsin treatment. It is likely that no single method can provide simultaneous labeling of receptor subunits in all locations.

\section{Detection of GluR1-pS845 after capsaicin injection}

Strong punctate immunostaining corresponding to GluR1pS845 was observed in sections from the rats that received injections of capsaicin $10 \mathrm{~min}$ before fixation. This was primarily restricted to the medial half of laminas I-II on the ipsilateral side (Figs. 7, $8 a-f$ ), although a few moderately immunoreactive puncta were seen on the contralateral side. The distribution of strongly labeled puncta in the medial part of the ipsilateral superficial dorsal horn matches that of nociceptive afferents that innervate the plantar surface of the foot. The GluR1-pS845-immunoreactive puncta were almost invariably also labeled with the GluR2 antibody (Fig. $8 a-c$; Table 4) but were greatly outnumbered by GluR2immunoreactive puncta that lacked GluR1-pS845 immunoreactivity. Between 67 and 126 puncta with pixels exceeding the threshold luminance value were seen ipsilaterally in medial laminas I-II in a single optical section $\left(1.66-3.3 / 1000 \mu \mathrm{m}^{2}\right)$ compared with between 4 and 14 puncta $\left(0.1-0.37 / 1000 \mu \mathrm{m}^{2}\right)$ in the corresponding part of the contralateral dorsal horn (Table 4). This difference was significant (Mann-Whitney, one-tailed $U$ test; $p<0.05$ ). Staining 
Table 2. Association of GluR1 and GluR2 puncta with VGLUT-immunoreactive boutons

\begin{tabular}{|c|c|c|c|c|c|c|c|c|}
\hline \multirow[b]{2}{*}{ Lamina } & \multicolumn{4}{|l|}{ VGLUT1 } & \multicolumn{4}{|l|}{ VGLUT2 } \\
\hline & $\begin{array}{l}\text { Percentage of } \\
\text { boutons with } \geq 1 \\
\text { GluR2 puncta }\end{array}$ & $\begin{array}{l}\text { Percentage of } \\
\text { boutons with } \geq 1 \\
\text { GluR1 puncta }\end{array}$ & $\begin{array}{l}\text { Mean GluR2 } \\
\text { puncta per } \\
\text { bouton }\end{array}$ & $\begin{array}{l}\text { Percentage of } \\
\text { GluR2 puncta } \\
\text { with GluR1 }\end{array}$ & $\begin{array}{l}\text { Percentage of } \\
\text { boutons with } \geq 1 \\
\text { GluR2 puncta }\end{array}$ & $\begin{array}{l}\text { Percentage of } \\
\text { boutons with } \geq 1 \\
\text { GluR1 puncta }\end{array}$ & $\begin{array}{l}\text { Mean GluR2 } \\
\text { puncta per } \\
\text { bouton }\end{array}$ & $\begin{array}{l}\text { Percentage of } \\
\text { GluR2 puncta } \\
\text { with GluR1 }\end{array}$ \\
\hline I & $\begin{array}{l}91.7 \\
(89-94)\end{array}$ & $\begin{array}{l}40.3 \\
(34-44)\end{array}$ & $\begin{array}{l}1.9 \\
(1.6-2.3)\end{array}$ & $\begin{array}{l}29.8^{* *} \\
(23.1-35.0)\end{array}$ & $\begin{array}{l}92 \\
(88-100)\end{array}$ & $\begin{array}{l}16.7 \\
(9-24)\end{array}$ & $\begin{array}{l}1.4 \\
(1.1-1.7)\end{array}$ & $\begin{array}{l}12.9 \\
(8.2-17.2)\end{array}$ \\
\hline$\|_{0}$ & $\begin{array}{l}95.0 \\
(91-99)\end{array}$ & $\begin{array}{l}64.3 \\
(53-71)\end{array}$ & $\begin{array}{l}2.8 \\
(2.6-3.4)\end{array}$ & $\begin{array}{l}40.2 \\
(30.7-55.0)\end{array}$ & $\begin{array}{l}97.3 \\
(96-100)\end{array}$ & $\begin{array}{l}24.7 \\
(19-28)\end{array}$ & $\begin{array}{l}1.6 \\
(1.4-1.8)\end{array}$ & $\begin{array}{l}17.0^{*} \\
(15.4-19.6)\end{array}$ \\
\hline Ili & $\begin{array}{l}98.3 \\
(97-100)\end{array}$ & $\begin{array}{l}76.3 \\
(73-82)\end{array}$ & $\begin{array}{l}4.2 \\
(3.4-4.7)\end{array}$ & $\begin{array}{l}38.1^{* *} \\
(32.7-41.0)\end{array}$ & $\begin{array}{l}96.7 \\
(92-100)\end{array}$ & $\begin{array}{l}24 \\
(16-29)\end{array}$ & $\begin{array}{l}1.6 \\
(1.4-1.7)\end{array}$ & $\begin{array}{l}16.9 \\
(11.6-20.6)\end{array}$ \\
\hline III & $\begin{array}{l}96.0 \\
(95-97)\end{array}$ & $\begin{array}{l}44.3 \\
(30-60)\end{array}$ & $\begin{array}{l}3.7 \\
(3.0-4.2)\end{array}$ & $\begin{array}{l}19.0^{* * *} \\
(15.5-24.0)\end{array}$ & $\begin{array}{l}95 \\
(90-100)\end{array}$ & $\begin{array}{c}5 \\
(4-7)\end{array}$ & $\begin{array}{l}1.4 \\
(1.3-1.5)\end{array}$ & $\begin{array}{l}3.6 \\
(2.7-4.9)\end{array}$ \\
\hline IV & $\begin{array}{l}93 \\
(89-95)\end{array}$ & $\begin{array}{l}31.7 \\
(29-33)\end{array}$ & $\begin{array}{l}2.6 \\
(2.2-3.2)\end{array}$ & $\begin{array}{l}19.4^{* *} \\
(14.7-24.9)\end{array}$ & $\begin{array}{l}96.7 \\
(96-98)\end{array}$ & $\begin{array}{c}4.3 \\
(0-11)\end{array}$ & $\begin{array}{l}1.6 \\
(1.4-1.9)\end{array}$ & $\begin{array}{c}1.9^{* * *} \\
(0-4.3)\end{array}$ \\
\hline V & $\begin{array}{l}94 \\
(91-99)\end{array}$ & $\begin{array}{l}21 \\
(16-26)\end{array}$ & $\begin{array}{l}2.6 \\
(2.4-2.9)\end{array}$ & $\begin{array}{l}10.4^{* *} \\
(7.3-14.0)\end{array}$ & $\begin{array}{l}97.7 \\
(95-100)\end{array}$ & $\begin{array}{l}1.7 \\
(0-4)\end{array}$ & $\begin{array}{l}1.5 \\
(1.2-1.7)\end{array}$ & $\begin{array}{l}0.8^{*} \\
(0-1.9)\end{array}$ \\
\hline IX & $\begin{array}{l}97.3 \\
(97-98)\end{array}$ & $\begin{array}{c}4.3 \\
(0-11)\end{array}$ & $\begin{array}{l}5.5 \\
(3.9-6.4)\end{array}$ & $\begin{array}{c}0.8^{* *} \\
(0-1.8)\end{array}$ & $\begin{array}{l}97.7 \\
(97-99)\end{array}$ & 0 & $\begin{array}{l}1.9 \\
(1.6-2.2)\end{array}$ & 0 \\
\hline
\end{tabular}

The proportion of VGLUT1- and VGLUT2-immunoreactive boutons that were adjacent to GluR1 and GluR2 puncta, together with the mean number of GluR2 puncta that contacted each bouton in each group, and the percentage of these that were also GluR1 immunoreactive are shown. One hundred boutons with each type of VGLUT immunoreactivity were examined in each region in three rats. Ranges are given in parentheses. Very few puncta were GluR1 but not GluR2 immunoreactive. The number of these in the sample of 300 VGLUT-immunoreactive boutons in each group is indicated by asterisks as follows: *0ne; **two; ***three.

Table 3. Association of GluR1 and GluR2 puncta with CGRP- and IR4-labeled boutons

\begin{tabular}{|c|c|c|c|c|c|c|c|c|}
\hline \multirow[b]{2}{*}{ Lamina } & \multicolumn{4}{|l|}{ CGRP } & \multicolumn{4}{|l|}{ IB4 } \\
\hline & $\begin{array}{l}\text { Percentage of } \\
\text { boutons with } \geq 1 \\
\text { GluR2 puncta }\end{array}$ & $\begin{array}{l}\text { Percentage of } \\
\text { boutons with } \geq 1 \\
\text { GluR1 puncta }\end{array}$ & $\begin{array}{l}\text { Mean GluR2 } \\
\text { puncta per } \\
\text { bouton }\end{array}$ & $\begin{array}{l}\text { Percentage of } \\
\text { GluR2 puncta } \\
\text { with GluR1 }\end{array}$ & $\begin{array}{l}\text { Percentage of } \\
\text { boutons with } \geq 1 \\
\text { GluR2 puncta }\end{array}$ & $\begin{array}{l}\text { Percentage of } \\
\text { boutons with } \geq 1 \\
\text { GluR1 puncta }\end{array}$ & $\begin{array}{l}\text { Mean GluR2 } \\
\text { puncta per } \\
\text { bouton }\end{array}$ & $\begin{array}{l}\text { Percentage of } \\
\text { GluR2 puncta } \\
\text { with GluR1 }\end{array}$ \\
\hline $\begin{array}{l}\text { I } \\
\text { Ilo } \\
\text { Ili }\end{array}$ & $\begin{array}{l}93.3 \\
(92-94)\end{array}$ & $\begin{array}{l}50.3 \\
(38-58)\end{array}$ & $\begin{array}{l}2.6 \\
(2.4-2.9)\end{array}$ & $\begin{array}{l}34.4 \\
(27.0-42.3)\end{array}$ & 100 & $\begin{array}{l}77.3 \\
(69-93)\end{array}$ & $\begin{array}{l}4.8 \\
(4.5-5.2)\end{array}$ & $\begin{array}{l}30.7 \\
(24.9-35.4)\end{array}$ \\
\hline
\end{tabular}

The proportion of CGRP-immunoreactive and IB4-labeled boutons that were adjacent to GluR1 and GluR2 puncta, together with the mean number of GluR2 puncta that contacted each bouton in each group, and the percentage of these that were also GluR1 immunoreactive are shown. One hundred boutons of each type were examined from laminae I-Ilo (CGRP) or lamina II (IB4) in three rats. Ranges are given in parentheses. In these populations, all GluR1-immunoreactive puncta were also GluR2 positive.

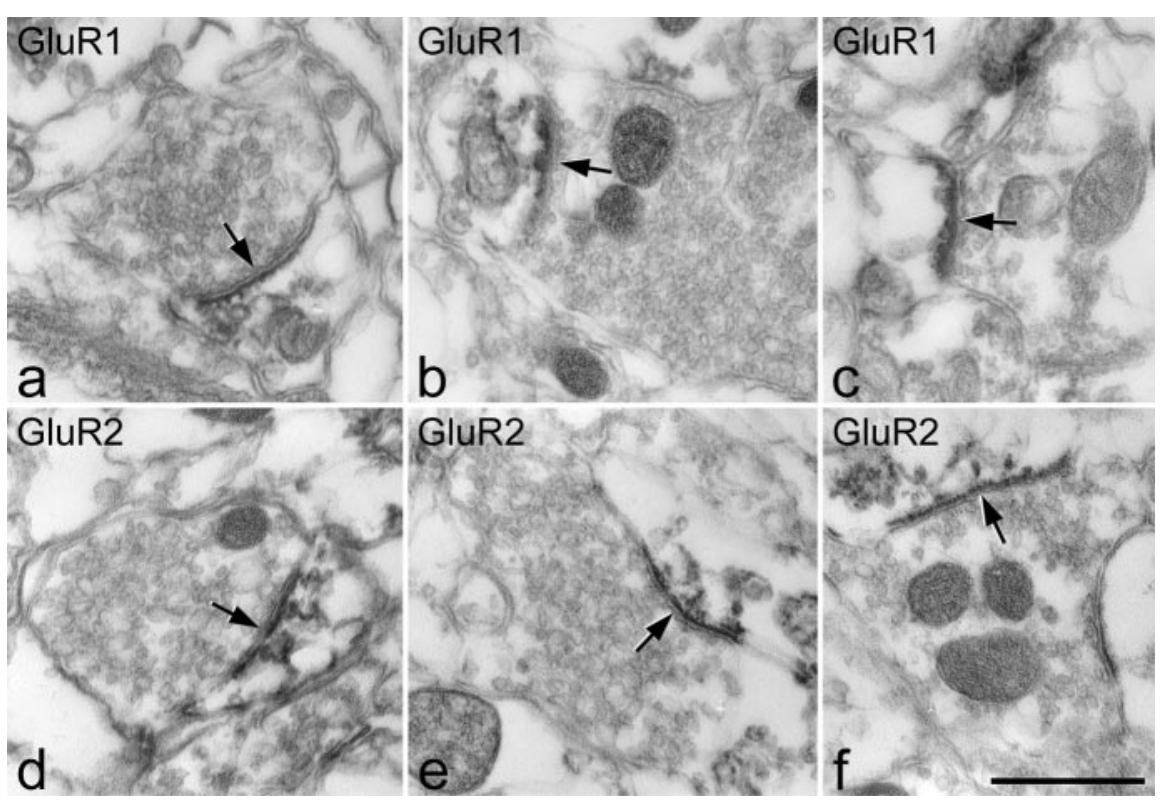

Figure 6. Electron microscopic appearance of GluR1 and GluR2 in the superficial dorsal horn after pepsin treatment. $a-c$ show GluR1 immunolabeling. $d-f$ show GluR2 immunolabeling. Immunoperoxidase reaction product is associated with the postsynaptic aspect of synapses (arrows). Scale bar, $0.5 \mu \mathrm{m}$.

was abolished by preabsorbing the antibody with the phosphopeptide but not the dephosphopeptide (Fig. $8 g-i$ ), indicating that it is specific for GluR1-pS845.

In addition to the strongly labeled puncta, numerous very weakly immunoreactive puncta were seen throughout the superficial dorsal horn on both sides with the GluR1-pS845 antibody, and again these were generally also GluR2 immunoreactive. This weak staining is likely to reflect a low basal level of phosphorylation of GluR1 subunits at glutamatergic synapses, whereas the substantial increase in staining in the medial part of the superficial dorsal horn ipsilaterally presumably results from increased phosphorylation of GluR1 at S845 in response to capsaicin injection (Fang et al., 2003).

\section{Discussion}

The main finding of this study was that antigen unmasking with pepsin revealed punctate labeling for all four AMPA receptor subunits in the spinal cord. These puncta represent synaptic receptors, as judged by their relationship with glutamatergic boutons and the results of electron microscopy. There was extensive colocalization between the subunits, with GluR2 being present at nearly all immunoreactive puncta throughout the gray matter, which suggests that GluR2 is almost universally expressed at AMPA-containing synapses throughout the spinal cord. In addition, we showed that noxious stimulation leads to phosphorylation of synaptic GluR1 subunits at the S845 residue. 

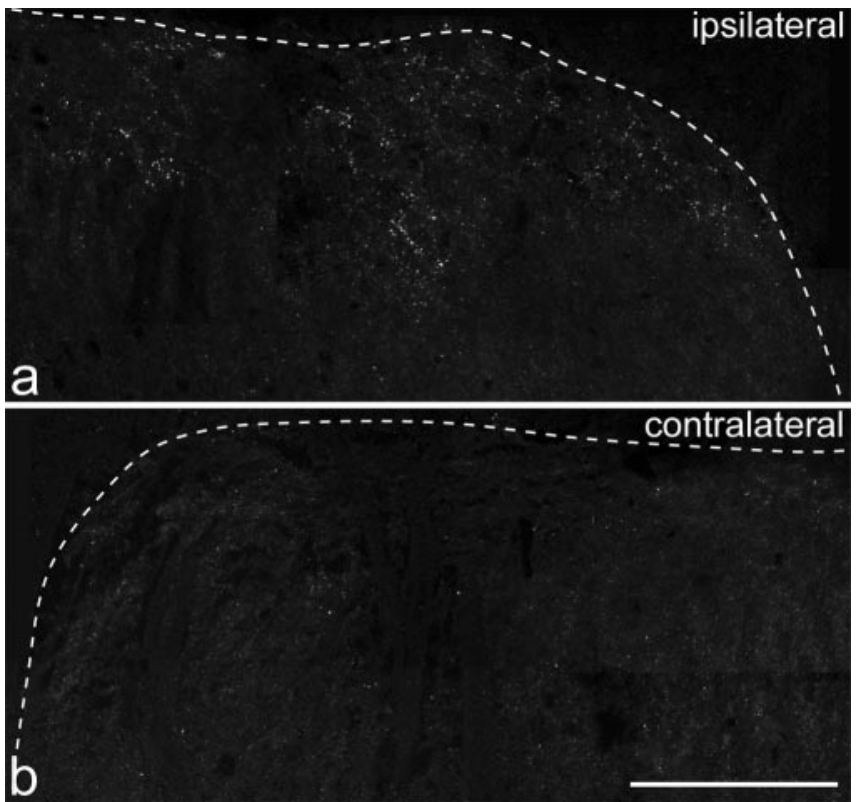

Figure 7. Immunostaining for GluR1-pS845 in a section from L4 in a rat that received an intraplantar capsaicin injection. a shows the medial part of the superficial dorsal horn on the left side (ipsilateral to the injection), and $b$ shows the corresponding part of the right dorsal horn. The dotted line indicates the border between gray and white matter. Numerous immunoreactive puncta are visible in the superficial laminas on the ipsilateral side, but these are rarely seen on the contralateral side. Each image was obtained from a projection of 11 optical sections at 0.5 $\mu \mathrm{m}$ z-separation. Scale bar, $100 \mu \mathrm{m}$.

\section{Laminar distribution of AMPA subunits and relationship to glutamatergic axons}

Although studies with in situ hybridization and conventional immunocytochemistry have provided information about the laminar distribution of neurons with different subunits, they do not allow us to determine the proportions of neurons that express a particular subunit or the extent of colocalization of subunits within neurons or at individual synapses. Based on the assumption that all spinal neurons possess AMPA receptors, our results suggest that at midlumbar levels, all (or virtually all) dorsal horn neurons and motoneurons express the GluR2 subunit, that GluR1 is restricted to certain dorsal horn cells (particularly those in the superficial laminas) and is not expressed by motoneurons, and that GluR3 and GluR4 are expressed by all (or virtually all) motoneurons, by the great majority of neurons in the deep dorsal horn (laminas III-V), and by some of those in the superficial laminas. The extensive colocalization of GluR2, GluR3, and GluR4 at puncta in laminas IV, V, and IX suggests that neurons in these laminas have all three subunits at the great majority of synapses that possess AMPA receptors.

Because our findings suggest that the GluR2 subunit is almost universally present at AMPA-containing synapses in midlumbar spinal cord, we examined the relationship of GluR2 to several types of glutamatergic axon. Most VGLUT1-immunoreactive boutons from lamina IIi-IX are central terminals of myelinated primary afferents, whereas the majority of VGLUT2-containing axons are probably derived from excitatory interneurons (Todd et al., 2003). We found that VGLUT1 boutons were adjacent to significantly more puncta than those with VGLUT2 in all laminas examined. Puncta seen with confocal microscopy do not necessarily represent individual synapses but could correspond to active sites within a synapse. Many VGLUT1-immunoreactive profiles in lamina IX are terminals of Ia muscle-spindle afferents
(Todd et al., 2003). Pierce and Mendell (1993) reported that most Ia afferent boutons in the cat were presynaptic to a single element, but that the mean number of active sites at these synapses was 6.1. The mean number of GluR2 puncta that we found on VGLUT1 boutons in lamina IX was 5.5, and these puncta therefore presumably correspond to active sites within individual synapses. VGLUT1-immunoreactive boutons in laminas IIi and III probably include $A \delta$ down-hair afferents, which form central axons of type II synaptic glomeruli (Réthelyi et al., 1982; Ribeiro-da-Silva and Coimbra, 1982), and we often observed clusters of GluR2 puncta surrounding VGLUT1 axons in this region. A $\beta$ afferents terminate widely in laminas III-V and form simpler synaptic arrangements on a few different postsynaptic elements (Maxwell and Réthelyi, 1987). Consistent with this, the number of puncta associated with VGLUT1 boutons was lower in laminas IV and V. Less is known about synaptic connections formed by axons of excitatory interneurons, but the number of puncta associated with VGLUT2-immunoreactive boutons (1.4-1.9) suggests that these have simpler arrangements, in many cases with only a single postsynaptic element. Many of the IB4-labeled terminals correspond to type I synaptic glomeruli (Ribeiro-da-Silva and Coimbra, 1982), and these were also frequently surrounded by clusters of GluR2 puncta (Fig. 5).

Interestingly, the proportions of GluR2 puncta that were also GluR1 immunoreactive were significantly higher for VGLUT1 boutons than for VGLUT2 boutons in laminas I-IV, and in the superficial laminas IB4- and CGRP-labeled boutons were also associated with more GluR1 puncta than were VGLUT2 boutons. This suggests that GluR1 is more often present at synapses formed by primary afferents than at those formed by excitatory interneurons. There are two possible explanations for this: either neurons that express GluR1 receive relatively more primary afferent synapses than other neurons, or alternatively GluR1 is selectively targeted to synapses formed by primary afferents. Selective targeting of AMPA subunits has been reported previously in the CNS (Rubio and Wenthold, 1997). The presence of GluR1 at synapses formed by nociceptive afferents is important because GluR1 (and GluR4-)-containing receptors are inserted into glutamatergic synapses in response to synaptic activity, unlike those that contain only GluR2 or GluR3, which are constitutively inserted (Bredt and Nicoll, 2003). This suggests that insertion of new receptor subunits could contribute to activity-dependent plasticity at synapses formed by these afferents.

Baba et al. (2000) reported that silent synapses (those with NMDA but not AMPA receptors) were extremely rare in laminas II-III of the adult rat spinal cord. Although we cannot determine the proportion of glutamatergic synapses at which AMPA receptors were present, our finding that fewer than 5\% of 3000 glutamatergic boutons analyzed in laminas I-III lacked GluR2 puncta is consistent with this observation.

\section{$\mathrm{Ca}^{2+}$-permeable AMPA receptors}

One of the major interests in AMPA receptors in the spinal cord has been the presence of $\mathrm{Ca}^{2+}$-permeable receptors. These have been identified on both dorsal horn neurons (Engelman et al., 1999; Stanfa et al., 2000) and motoneurons (Vandenberghe et al., 2001; van Damme et al., 2002). $\mathrm{Ca}^{2+}$-permeable AMPA receptors in the dorsal horn are thought to be responsible for tactile allodynia after a noxious thermal stimulus or carrageenaninduced inflammation (Sorkin et al., 1999, 2001). Those on motoneurons appear to be involved in the excitotoxicity that is thought to underlie amyotrophic lateral sclerosis. $\mathrm{Ca}^{2+}$ permeability is prevented by the presence of GluR2 subunits in which 

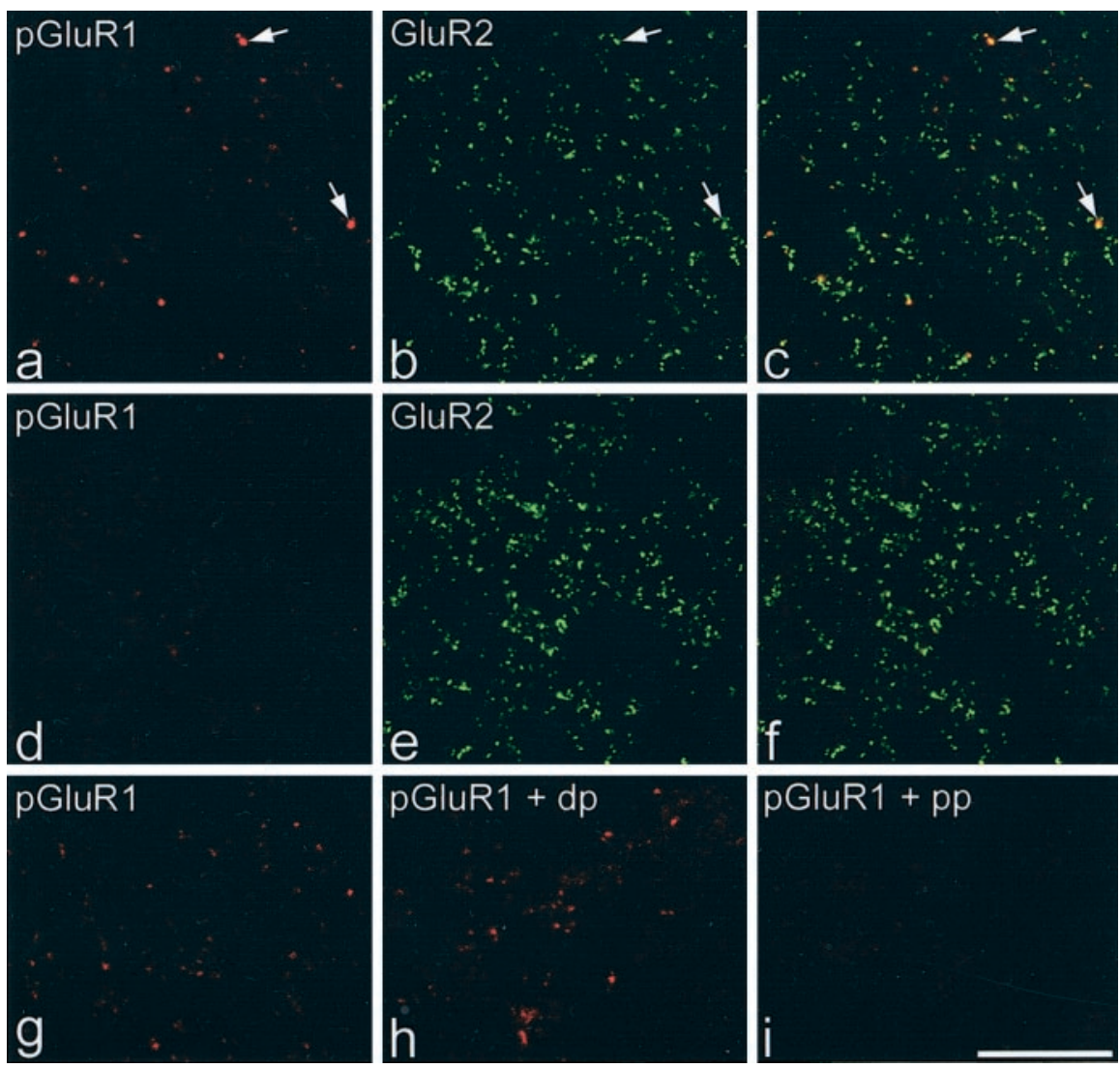

Figure 8. High-magnification views of GluR1-pS845 staining and absorption controls. a-c show part of laminas I and II on the side ipsilateral to the capsaicin injection (from the section illustrated in Fig. 7). Several puncta that are strongly labeled with the GluR1-pS845 antibody (red) are visible (2 indicated with arrows). All of these are also GluR2 immunoreactive (green) and appear yellow in the merged image. $d-f$, A similar region from the superficial dorsal horn on the contralateral side of the same section. GluR1-pS845 staining is much fainter. $g-i$ show corresponding parts of the superficial dorsal horn ipsilateral to the capsaicin injection in sections reacted with GluR1-pS845 antibody. The section in $h$ was preincubated in dephosphopeptide (dp), that in $i$ in phosphopeptide (pp), whereas that in $g$ did not have any peptide added. Each of these sections is from the same animal and was scanned under identical conditions. The punctate immunostaining is abolished by the phosphopeptide but is not affected by the dephosphopeptide. All images are from single optical sections. Scale bar, $20 \mu \mathrm{m}$.

Table 4. pSer845 GluR1 immunoreactivity after injection of capsaicin

\begin{tabular}{|c|c|c|c|c|c|c|}
\hline \multirow[b]{2}{*}{ Rat } & \multicolumn{3}{|l|}{ Left } & \multicolumn{3}{|l|}{ Right } \\
\hline & $\begin{array}{l}\text { pSer845 GluR1 } \\
\text { puncta }\end{array}$ & $\begin{array}{l}\text { pSer845 GluR1 } \\
\text { puncta per } 1000 \mu \mathrm{m}^{2}\end{array}$ & $\begin{array}{l}\text { Percentage } \\
\text { with GluR2 }\end{array}$ & $\begin{array}{l}\text { pSer845 GluR1 } \\
\text { puncta }\end{array}$ & $\begin{array}{l}\text { pSer845 GluR1 } \\
\text { puncta per } 1000 \mu \mathrm{m}^{2}\end{array}$ & $\begin{array}{l}\text { Percentage } \\
\text { with GluR2 }\end{array}$ \\
\hline 1 & 96 & 2.412 & 99 & 14 & 0.372 & 100 \\
\hline 2 & 126 & 3.295 & 100 & 4 & 0.097 & 50 \\
\hline 3 & 67 & 1.657 & 96 & 9 & 0.232 & 56 \\
\hline
\end{tabular}

The number of pSer845 GluR1-immunoreactive puncta in the medial half of each dorsal horn in a single optical section from three rats that received injections of $250 \mu \mathrm{g}$ of capsaicin into the plantar surface of the hindpaw $10 \mathrm{~min}$ before perfusion fixation. The table shows the total number of puncta containing at leas one pixel that exceeded the threshold luminance value (see Materials and Methods), the number of puncta per $1000 \mu \mathrm{m}^{2}$, and the proportion of these puncta that were also GluR2 immunoreactive. The density of pSer845 GluR1-immunoreactive puncta was significantly higher on the ipsilateral side than on the contralateral side $(p<0.05$; Mann-Whitney one-tailed $U$ test $)$

arginine at position 586 has been changed to glutamine by means of RNA editing. Because GluR2 subunits in the adult rat spinal cord are mostly in the edited form (Vandenberghe et al., 2000), it is likely that $\mathrm{Ca}^{2+}$-permeable AMPA receptors lack the GluR2 subunit. Our results suggest that all spinal neurons express GluR2, and therefore neurons that possess $\mathrm{Ca}^{2+}$-permeable AMPA receptors presumably also synthesize receptors that contain GluR2 and are $\mathrm{Ca}^{2+}$ impermeable (Vandenberghe et al., 2001; van Damme et al., 2002). Because AMPA receptor subunits may be selectively directed to particular postsynaptic targets on a neuron (Rubio and Wenthold, 1997), it is possible that some synapses might lack GluR2 and therefore have exclusively $\mathrm{Ca}^{2+}$ permeable receptors. Evidence for this has been provided by Vandenberghe et al. (2000), who reported that $8 \%$ of the clusters of GluR4 immunoreactivity on cell bodies and dendrites of cultured motoneurons were not GluR2 immunoreactive. However, our results suggest that in vivo, very few $(\approx 2 \%)$ active sites with AMPA receptors lack GluR2, even though the relative concentrations of the different subunits can vary considerably. It is therefore likely that for neurons with $\mathrm{Ca}^{2+}$-permeable AMPA receptors, these are intermingled with GluR2containing receptors within the same active sites.

\section{Phosphorylation of GluR1 subunits}

Phosphorylation of AMPA receptors is known to play an important role in both long-term potentiation (LTP) and depression (Song and Huganir, 2002; Bredt and Nicoll, 2003). The GluR1 subunit has two major phosphorylation sites, S831 and S845 (Roche et al., 1996), and mice in which these residues are mutated to prevent phosphorylation show reduced hippocampal LTP and loss of memory retention (Lee et al., 2003). Phosphorylation of GluR1 at the $\mathrm{S} 845$ site by protein kinase A results in a $40 \%$ enhancement of peak current flow through homomeric GluR1 channels in transfected cells (Roche et al., 1996) because of an increase in peak openchannel probability (Banke et al., 2000). In addition, phosphorylation of the $S 845$ site is necessary for the incorporation of additional GluR1 subunits into glutamatergic synapses that is thought to contribute to synaptic plasticity (Esteban et al., 2003).

AMPA receptor phosphorylation has also been implicated in the central sensitization of dorsal horn neurons that contributes to chronic pain states (Sandkühler, 2000; Fang et al., 2003; Ji et al., 2003). Our results suggest that there is normally a very low level of phosphorylation of GluR1 at the S845 site in glutamatergic synapses in the dorsal horn, but that this can be substantially increased in a subset of synapses in a somatotopically appropriate location within $10 \mathrm{~min}$ of capsaicin injection, a stimulus that is known to cause central sensitization (Simone et al., 1991). Interestingly, Chung et al. (2000) reported that although there were relatively high levels of phosphorylated GluR2 (at S880) in dendritic shafts of cultured hippocampal neurons, the level of phosphorylation at synapses was very low, and that activation of protein kinase $\mathrm{C}$ resulted in phosphorylation of synaptic receptors.

Our study apparently provides the first demonstration of phosphorylation of iGluRs at synapses in vivo. It reveals that noxious stimulation induces rapid phosphorylation of GluR1 subunits at glutamatergic synapses and provides a novel approach for 
investigating central sensitization and other forms of synaptic plasticity in specific neuronal circuits throughout the CNS.

\section{References}

Baba H, Doubell TP, Moore KA, Woolf CJ (2000) Silent NMDA-mediated synapses are developmentally regulated in the dorsal horn of the rat spinal cord. J Neurophysiol 83:955-962.

Banke TG, Bowie D, Lee H-K, Huganir RL, Schousboe A, Traynelis SF (2000) Control of GluR1 AMPA receptor function by c-AMP-dependent protein kinase. J Neurosci 20:89-102.

Bar-Peled O, O’Brien RJ, Morrison JH, Rothstein JD (1999) Cultured motor neurons possess calcium-permeable AMPA/kainate receptors. NeuroReport 10:855-859.

Baude A, Nusser Z, Molnár E, McIlhinney RAJ, Somogyi P (1995) Highresolution immunogold localization of AMPA type glutamate receptor subunits at synaptic and non-synaptic sites in rat hippocampus. Neuroscience 69:1031-1055.

Bredt DS, Nicoll RA (2003) AMPA receptor trafficking at excitatory synapses. Neuron 40:361-379.

Broman J (1994) Neurotransmitters in subcortical somatosensory pathways. Anat Embryol (Berl) 189:181-214.

Chung HJ, Xia J, Scannevin RH, Zhang Z, Huganir RL (2000) Phosphorylation of the AMPA receptor subunit GluR2 differentially regulates its interaction with PDZ domain-containing proteins. J Neurosci 20:7258-7267.

Coggeshall RE, Carlton SM (1997) Receptor localization in the mammalian dorsal horn and primary afferent neurons. Brain Res Brain Res Rev 24:28-66.

Del Caño GG, Millán LM, Gerrikagoitia I, Sarasa M, Matute C (1999) Ionotropic glutamate receptor subunit distribution on hypoglossal motoneuronal pools in the rat. J Neurocytol 28:455-468.

Dickenson AH, Chapman V, Green GM (1997) The pharmacology of excitatory and inhibitory amino acid-mediated events in the transmission and modulation of pain in the spinal cord. Gen Pharmacol 28:633-638.

Dingledine R, Borges K, Bowie D, Traynelis SF (1999) The glutamate receptor ion channels. Pharmacol Rev 51:7-61.

Engelman HS, Allen TB, MacDermott AB (1999) The distribution of neurons expressing calcium-permeable AMPA receptors in the superficial laminae of the spinal cord. J Neurosci 19:2081-2089.

Esteban JA, Shi S-H, Wilson C, Nuriya M, Huganir RL, Malinow R (2003) PKA phosphorylation of AMPA receptor subunits controls synaptic trafficking underlying plasticity. Nat Neurosci 6:136-143.

Fang LI, Wu J, Zhang X, Lin Q, Willis WD (2003) Increased phosphorylation of the GluR1 subunit of the spinal cord $\alpha$-amino-3-hydroxy-5methyl-4-isoxazolepropionate receptor in rats following intradermal injection of capsaicin. Neuroscience 122:237-245.

Fritschy J-M, Weinmann O, Wenzel A, Benke D (1998) Synapse-specific localization of NMDA and $\mathrm{GABA}_{\mathrm{A}}$ receptor subunits revealed by antigenretrieval immunohistochemistry. J Comp Neurol 390:194-210.

Fukaya M, Watanabe M (2000) Improved immunohistochemical detection of postsynaptically located PSD-95/SAP90 protein family by protease section pretreatment: a study in the adult mouse brain. J Comp Neurol 426:572-586.

Furuyama T, Kiyama H, Sato K, Park HT, Maeno H, Takagi H, Tohyama M (1993) Region-specific expression of subunits of ionotropic glutamate receptors (AMPA-type, KA-type and NMDA receptors) in the rat spinal cord with special reference to nociception. Mol Brain Res 18:141-151.

Harris JA, Corsi M, Quartaroli M, Arban R, Bentivoglio M (1996) Upregulation of spinal glutamate receptors in chronic pain. Neuroscience $74: 7-12$.

Henley JM, Jenkins R, Hunt SP (1993) Localisation of glutamate receptor binding sites and mRNAs to the dorsal horn of the rat spinal cord. Neuropharmacology 32:37-41.

Jakowec MW, Fox AJ, Martin LJ, Kalb RG (1995a) Quantitative and qualitative changes in AMPA receptor expression during spinal cord development. Neuroscience 67:893-907.

Jakowec MW, Yen L, Kalb RG (1995b) In situ hybridization analysis of AMPA receptor subunit gene expression in the developing rat spinal cord. Neuroscience 67:909-920.

Ji R-R, Kohno T, Moore KA, Woolf CJ (2003) Central sensitization and LTP: do pain and memory share similar mechanisms. Trends Neurosci 26:696-705.
Lee HK, Takamiya K, Han JS, Man H, Kim CH, Rumbaugh G, Yu S, Ding L, He C, Petralia RS, Wenthold RJ, Gallagher M, Huganir RL (2003) Phosphorylation of the AMPA receptor GluR1 subunit is required for synaptic plasticity and retention of spatial memory. Cell 112:631-643.

Lu CR, Hwang SJ, Phend KD, Rustioni A, Valtschanoff JG (2002) Primary afferent terminals in spinal cord express presynaptic AMPA receptors. J Neurosci 22:9522-9529.

Maxwell DJ, Réthelyi M (1987) Ultrastructure and synaptic connections of cutaneous afferent fibres in the spinal cord. Trends Neurosci 10:117-123.

Morrison BM, Janssen WGM, Gordon JW, Morrison JH (1998) Light and electron microscopic distribution of the AMPA receptor subunit, GluR2, in the spinal cord of control and G86R mutant superoxide dismutase transgenic mice. J Comp Neurol 395:523-534.

Ottersen OP, Landsend AS (1997) Organization of glutamate receptors at the synapse. Eur J Neurosci 9:2219-2224.

Pellegrini-Giampietro DE, Fan S, Ault B, Miller BE, Zukin RS (1994) Glutamate receptor gene expression in spinal cord of arthritic rats. J Neurosci 14:1576-1583.

Pierce JP, Mendell LM (1993) Quantitative ultrastructure of Ia boutons in the ventral horn: scaling and positional relationships. J Neurosci 13:4748-4763.

Popratiloff A, Weinberg RJ, Rustioni A (1996) AMPA receptor subunits underlying terminals of fine-caliber primary afferent fibers. J Neurosci 16:3363-3372.

Popratiloff A, Weinberg RJ, Rustioni A (1998) AMPA receptors at primary afferent synapses in substantia gelatinosa after sciatic nerve section. Eur J Neurosci 10:3220-3230.

Ragnarson B, Ornung G, Grant G, Ottersen OP, Ulfhake B (2003) Glutamate and AMPA receptor immunoreactivity in Ia synapses with motoneurons and neurons of the central cervical nucleus. Exp Brain Res 149:447-457.

Réthelyi M, Light AR, Perl ER (1982) Synaptic complexes formed by functionally defined primary sensory afferent units with fine myelinated fibers. J Comp Neurol 207:381-393.

Ribeiro-da-Silva A, Coimbra A (1982) Two types of synaptic glomeruli and their distribution in laminae I-III of the rat spinal cord. J Comp Neurol 209:176-186.

Roche KW, O’Brien RJ, Mammen AL, Bernhardt J, Huganir RL (1996) Characterization of multiple phosphorylation sites on the AMPA receptor GluR1 subunit. Neuron 16:1179-1188.

Rubio ME, Wenthold RJ (1997) Glutamate receptors are selectively targeted to postsynaptic sites in neurons. Neuron 18:939-950.

Sakamoto H, Spike RC, Todd AJ (1999) Neurons in laminae III and IV of the rat spinal cord with the neurokinin-1 receptor receive few contacts from unmyelinated primary afferents which do not contain substance $P$. Neuroscience 94:903-908.

Sandkühler J (2000) Learning and memory in pain pathways. Pain 88:113-118.

Shaw PJ, Williams TL, Slade JY, Eggett CJ, Ince PG (1999) Low expression of GluR2 AMPA receptor subunit protein by human motor neurons. NeuroReport 10:261-265.

Shibata T, Watanabe M, Ichikawa R, Inoue Y, Koyanagi T (1999) Differential expressions of $\alpha$-amino-3-hydroxy-5-methyl-4-isoxazolepropionic acid and $N$-methyl-D-aspartate receptor subunit mRNAs between visceromotor and somatomotor neurons of the rat lumbosacral spinal cord. J Comp Neurol 404:172-182.

Simone DA, Sorkin LS, Oh U, Chung JM, Owens C, LaMotte RH, Willis WD (1991) Neurogenic hyperalgesia: central neural correlates in responses of spinothalamic tract neurons. J Neurophysiol 66:228-246.

Song I, Huganir RL (2002) Regulation of AMPA receptors during synaptic plasticity. Trends Neurosci 25:578-588.

Sorkin LS, Yaksh TL, Doom CM (1999) Mechanical allodynia in rats is blocked by a $\mathrm{Ca}^{2+}$ permeable AMPA receptor antagonist. NeuroReport 10:3523-3526.

Sorkin LS, Yaksh TL, Doom CM (2001) Pain models display differential sensitivity to $\mathrm{Ca}^{2+}$-permeable non-NMDA glutamate receptor antagonists. Anesthesiology 95:965-973.

Spike RC, Kerr R, Maxwell DJ, Todd AJ (1998) GluR1 and GluR2/3 subunits of the AMPA-type glutamate receptor are associated with particular types of neuron in laminae I-III of the spinal dorsal horn of the rat. Eur J Neurosci 10:324-333. 
Stanfa LC, Hampton DW, Dickenson AH (2000) Role of $\mathrm{Ca}^{2+}$-permeable non-NMDA glutamate receptors in spinal nociceptive transmission. NeuroReport 11:3199-3202.

Tachibana M, Wenthold RJ, Morioka H, Petralia RS (1994) Light and electron microscopic immunocytochemical localization of AMPA-selective glutamate receptors in the rat spinal cord. J Comp Neurol 344:431-454.

Temkin R, Lowe D, Jensen P, Hatt H, Smith DO (1997) Expression of glutamate receptor subunits in alpha-motoneurons. Mol Brain Res 52:38-45.

Todd AJ, Hughes DI, Polgár E, Nagy GG, Mackie M, Ottersen OP, Maxwell DJ (2003) The expression of vesicular glutamate transporters VGLUT1 and VGLUT2 in neurochemically-defined axonal populations in the rat spinal cord with emphasis on the dorsal horn. Eur J Neurosci 17:13-27.

Tölle TR, Berthele A, Zieglgansberger W, Seeburg PH, Wisden W (1993) The differential expression of 16 NMDA and non-NMDA receptor subunits in the rat spinal cord and in periaqueductal grey. J Neurosci 13:5009-5028.

Tölle TR, Berthele A, Zieglgansberger W, Seeburg PH, Wisden W (1995) Flip and flop variants of AMPA receptors in the rat lumbar spinal cord. Eur J Neurosci 7:1414-1419.

van Damme P, van den Bosch L, van Houtte E, Callewaert G, Robberecht W (2002) GluR2-dependent properties of AMPA receptors determine the selective vulnerability of motor neurons to excitotoxicity. J Neurophysiol 88:1279-1287.

Vandenberghe W, Robberecht W, Brorson JR (2000) AMPA receptor calcium permeability, GluR2 expression, and selective motoneuron vulnerability. J Neurosci 20:123-132.

Vandenberghe W, Bindokas VP, Miller RJ, Robberecht W, Brorson JR
(2001) Subcellular localization of calcium-permeable AMPA receptors in spinal motoneurons. Eur J Neurosci 14:305-314.

Varoqui H, Schäfer MK-H, Zhu H, Weihe E, Erickson JD (2002) Identification of the differentiation-associated $\mathrm{Na}^{+} / \mathrm{P}_{\mathrm{I}}$ transporter as a novel vesicular glutamate transporter expressed in a distinct set of glutamatergic synapses. J Neurosci 22:142-155.

Virgo L, Samarasinghe S, de Belleroche J (1996) Analysis of AMPA receptor subunit mRNA expression in control and ALS spinal cord. NeuroReport 7:2507-2511.

Vissavajjhala P, Janssen WG, Hu Y, Gazzaley AH, Moran T, Hof PR, Morrison JH (1996) Synaptic distribution of the AMPA-GluR2 subunit and its colocalization with calcium-binding proteins in rat cerebral cortex: an immunohistochemical study using a GluR2-specific monoclonal antibody. Exp Neurol 142:296-312.

Watanabe M, Fukaya M, Sakimura K, Manabe T, Mishina M, Inoue Y (1998) Selective scarcity of NMDA receptor channel subunits in the stratum lucidum (mossy fibre-recipient layer) of the mouse hippocampal CA3 subfield. Eur J Neurosci 10:478-487.

Williams TL, Day NC, Ince PG, Kamboj RK, Shaw PJ (1997) Calciumpermeable alpha-amino-3-hydroxy-5-methyl-4-isoxazole propionic acid receptors: a molecular determinant of selective vulnerability in amyotrophic lateral sclerosis. Ann Neurol 42:200-207.

Yoshimura M, Jessell T (1990) Amino acid-mediated EPSPs at primary afferent synapses with substantia gelatinosa neurones in the rat spinal cord. J Neurophysiol 430:315-335.

Yoshimura M, Nishi S (1992) Excitatory amino acid receptors involved in primary afferent-evoked polysynaptic EPSPs of substantia gelatinosa neurons in the adult rat spinal cord slice. Neurosci Lett 143:131-134. 